Use of veterinary medicines, feed additives and probiotics in four major internationally traded aquaculture species farmed in Asia

Rico, Andreu; Phu, Tran; Satapornvanit, Kriengkrai ; Min, Jiang ; Shahabuddin, A. M.;

Henriksson, Patrik J. G.; Murray, Francis J.; Little, David C.; Dalsgaard, Anders; Van den Brink, Paul J.

Published in:

Aquaculture

DOI:

10.1016/j.aquaculture.2013.07.028

Publication date:

2013

Document version

Early version, also known as pre-print

Citation for published version (APA):

Rico, A., Phu, T., Satapornvanit, K., Min, J., Shahabuddin, A. M., Henriksson, P. J. G., Murray, F. J., Little, D. C., Dalsgaard, A., \& Van den Brink, P. J. (2013). Use of veterinary medicines, feed additives and probiotics in four major internationally traded aquaculture species farmed in Asia. Aquaculture, 412-413, 231-243.

https://doi.org/10.1016/j.aquaculture.2013.07.028 


\title{
Use of veterinary medicines, feed additives and probiotics in four major internationally traded aquaculture species farmed in Asia
}

\author{
Andreu Rico $^{\text {a,* }}$, Tran Minh Phu b,c ${ }^{\text {, Kriengkrai Satapornvanit }}{ }^{\text {, }}$ Jiang Min ${ }^{\text {e }}$, A.M. Shahabuddin ${ }^{\text {f,g }}$, \\ Patrik J.G. Henriksson ${ }^{\text {h}}$, Francis J. Murray ${ }^{i}$, David C. Little ${ }^{\mathrm{i}}$, Anders Dalsgaard ${ }^{\mathrm{c}}$, Paul J. Van den Brink ${ }^{\mathrm{a}, \mathrm{j}}$ \\ a Department of Aquatic Ecology and Water Quality Management, Wageningen University, Wageningen University and Research Centre, P.O. Box 47, AA Wageningen 6700, The Netherlands \\ b College of Aquaculture and Fisheries, Can Tho University, 3/2 Street, Campus II, Can Tho, Vietnam \\ c Faculty of Health and Medical Sciences, University of Copenhagen, Stigböjlen 4, 1870 Frederiksberg C, Denmark \\ d Department of Fishery Biology, Faculty of Fisheries, Kasetsart University, Chatuchak, 10900 Bangkok, Thailand \\ e College of Fisheries and Life Science, Shanghai Ocean University, P.O. Box 181, 201306 Shanghai, China \\ ${ }^{\mathrm{f}}$ Department of Fisheries, Sher-e-Bangla Agricultural University, Sher-e-Bangla Nagar, 1207 Dhaka, Bangladesh \\ ${ }^{g}$ Graduate School of Bioresources, Mie University, 1577 Kurimamachiya-cho, 514-8507 Tsu City, Japan \\ ${ }^{\text {h }}$ Department of Industrial Ecology, Institute of Environmental Sciences, Leiden University, 2333 CC Leiden, The Netherlands \\ i Institute of Aquaculture, University of Stirling, FK9 4LA Stirling, United Kingdom \\ j Alterra, Wageningen University and Research Centre, P.O. Box 47, 6700 AA Wageningen, The Netherlands
}

\section{A R T I C L E I N F O}

\section{Article history:}

Received 10 May 2013

Received in revised form 11 July 2013

Accepted 15 July 2013

Available online 24 July 2013

\section{Keywords:}

Aquaculture

Veterinary medicines

Shrimp

Pangasius

Tilapia

Asia

\begin{abstract}
A B S T R A C T
Antimicrobials, parasiticides, feed additives and probiotics are used in Asian aquaculture to improve the health status of the cultured organisms and to prevent or treat disease outbreaks. Detailed information on the use of such chemicals in Asian aquaculture is limited, but of crucial importance for the evaluation of their potential human health and environmental risks. This study reports the outcomes of a survey on the use of chemical and biological products in 252 grow-out aquaculture farms and 56 farm supply shops in four countries in Asia. The survey was conducted between 2011 and 2012, and included nine aquaculture farm groups: Penaeid shrimp farms in Bangladesh, China, Thailand and Vietnam; Macrobrachium prawn farms, and farms producing both Penaeid shrimps and Macrobrachium prawns in Bangladesh; tilapia farms in China and Thailand; and Pangasius catfish farms in Vietnam. Results were analysed with regard to the frequencies of use of active ingredients and chemical classes, reported dosages, and calculated applied mass relative to production. A range of farm management and farm characteristics were used as independent variables to explain observed chemical use patterns reported by farmers within each group. Sixty different veterinary medicinal ingredients were recorded (26 antibiotics, 19 disinfectants, and 15 parasiticides). The use of antibiotic treatments was found to be significantly higher in the Vietnamese Pangasius farms. However, total quantities of antibiotics, relative to production, applied by the Pangasius farmers were comparable or even lower than those reported for other animal production commodities. Semi-intensive and intensive shrimp farms in China, Thailand and Vietnam showed a decrease in the use of antibiotic treatments. These farm groups utilised the largest amount of chemicals relative to production, with feed additives and plant extracts, probiotics, and disinfectants, being the most used chemical classes, mainly for disease prevention. The surveyed farmers generally did not exceed recommended dosages of veterinary medicines, and nationally or internationally banned compounds were (with one exception) reported neither by the surveyed farmers, nor by the surveyed chemical sellers. Factors underlying the observed differences in chemical use patterns differed widely amongst farm groups, and geographical location was found to be the only factor influencing chemical ingredient application patterns in the majority of the studied farm groups.
\end{abstract}

(c) 2013 Elsevier B.V. All rights reserved.

\section{Introduction}

The Asian aquaculture sector has grown at a rapid pace during recent decades, and nowadays accounts for nearly $90 \%$ of the global aquaculture production (FAO, 2012a). Intensification of aquaculture practices in Asian aquaculture has often been accompanied by more frequent

\footnotetext{
* Corresponding author. Tel.: + 31317486226

E-mail address: andreu.rico@wur.nl (A. Rico).
}

outbreaks of infectious diseases that require therapeutic treatment (Bondad-Reantaso et al., 2005). Natural and synthetic chemicals such as antibiotics, disinfectants, parasiticides, probiotics, and other feed additives have become indispensable inputs to treat and prevent bacterial and parasitic diseases, to improve water quality, and/or as growth promoters. The use of these substances has contributed to the productivity and growth of the Asian aquaculture sector, but has also attracted criticism. Chemical residues in the cultured organisms constitute a potential hazard for human consumers (Heuer et al., 2009; Sapkota 
et al., 2008), and indicate the fallibility of national and international food safety controls when they exceed food safety standards (Love et al., 2011). Moreover, the continued application of compounds such as antibiotics has been associated with the development of drug-resistant bacteria both inside and outside of aquaculture facilities (Le et al., 2005), and environmental residues of highly toxic substances, such as disinfectants or parasiticides, can exert toxic effects on non-target organisms, contributing to a potential degradation of ecosystems receiving aquaculture effluents (Rico et al., 2012).

The current information on the use of chemicals and biological products applied by Asian farmers is very limited, or even unavailable for some important aquaculture species (Rico et al., 2012). The Food and Agriculture Organization (FAO) reports the outcomes of a survey performed during 2009 on the use of aquaculture medicinal products on 12 different aquatic species groups, with special focus on four major aquaculture-producing countries in Asia (China, Philippines, Thailand and Vietnam) (Alday-Sanz et al., 2012). The outcomes of this survey show high frequencies of use for some Asian species groups (e.g. Pangasius, shrimp), and a greater availability of veterinary medicinal products in Asian markets compared to other regions (Alday-Sanz et al., 2012). However, with some exceptions, these data and other published data (see review by Rico et al., 2012) have limited scope for species and country-specific comparisons, since information was collected from different sources and actors in different years, and fail to provide detailed descriptions of dosages and volumes applied. The collection of detailed information on the use of antimicrobials and other chemical inputs in Asian aquaculture is of crucial importance to evaluate their potential risks for human health and for the environment, as well as to evaluate the prudent use of such compounds, and their effectiveness for preventing and treating disease outbreaks.

In the current study we assessed the use of veterinary compounds, feed additives and probiotics for four internationally traded aquatic species based on a systematic survey of 252 grow-out farms and 56 farm supply shops. The survey covered nine aquaculture farm groups with different levels of production intensity, thus potentially showing different chemical use patterns. These were: i) Penaeid shrimps in Bangladesh, China, Thailand and Vietnam, ii) Macrobrachium prawns, and concurrent shrimp and prawn production systems, in Bangladesh, iii) tilapia in China and Thailand, and iv) Pangasius catfish in Vietnam. This mix of countries and species was selected mainly due to their recent great increase in production and trade, both by volume and value (Fig. 1). The objective of the present study was two-fold. First, to quantitatively assess the current use of veterinary compounds, feed additives and probiotics in the aforementioned aquaculture farm groups and to compare them in terms of active ingredients used, actual vs recommended application dosages, and mass of chemicals applied relative to production. The second objective was to try to explain the differences in chemical use patterns observed in each of the studied aquaculture farm groups, in order to identify a potential relationship between the chemical use patterns and management characteristics of each aquaculture farm group. This was done by correlating data on farm-level aquaculture management practices and farm characteristics, with the data on chemicals and active ingredients used in the farms. The dataset provided by the current study offers the most extensive source of quantitative information on volumes and dosages of chemicals applied in Asian aquaculture, and constitutes a basis for on-going studies aimed at: i) assessing the appropriateness of the chemical use practices to treat and prevent disease outbreaks, ii) identifying occupational health hazards, and iii) performing human health and environmental risk assessments in each of the studied farm groups.

\section{Materials and methods}

\subsection{Chemical use interviews}

Information on the application of veterinary compounds, feed additives and probiotics was collected between 2011 and 2012 through structured interviews conducted with farm owners, managers or technical staff of 252 aquaculture grow-out farms (Table 1). These farms were selected as a sub-sample of more than 1,600 farms for which baseline data on aquaculture management practices, social and economic aspects had previously been collected in the SEAT project Primary Survey (Murray et al., 2013). The studied sub-set of aquaculture farms was selected taking into account species group, farm-scale and geographical location as selection variables (see Murray et al., 2013 for rationale). This farm selection was directed towards a wide

\section{a. Production volume}

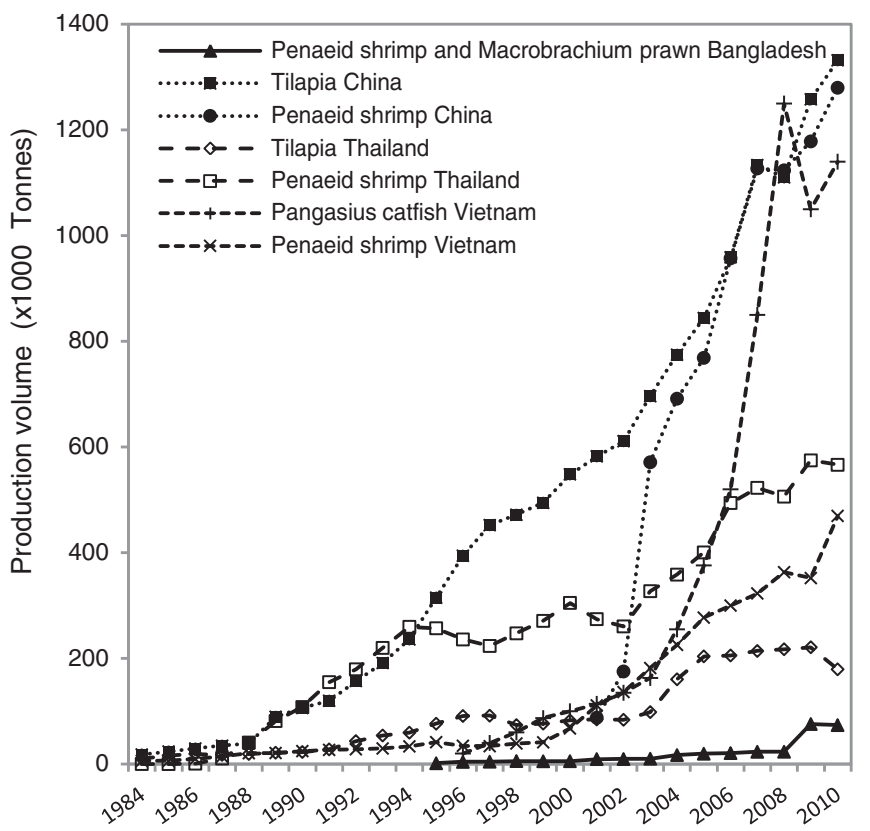

\section{b. Production value}

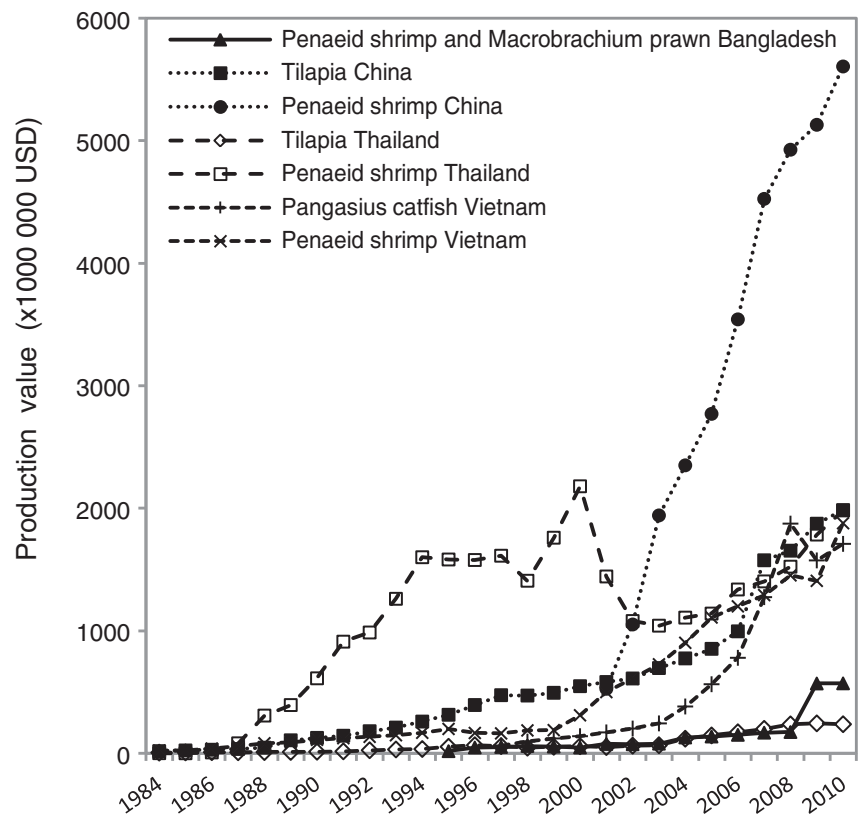

Fig. 1. Trends of (a) production volume and (b) production value over the last decades for the aquaculture species included in the present study (Data source: FAO, 2012b). 
Table 1

Characteristics of the interviewed farms and chemical use interviews.

\begin{tabular}{|c|c|c|c|c|c|c|}
\hline Country & Main species & Main production system ${ }^{a}$ & Region/province(s) & Interview dates & $\begin{array}{l}\text { Number } \\
\text { of farms }\end{array}$ & $\begin{array}{l}\text { Number } \\
\text { of } \\
\text { supply } \\
\text { shops }\end{array}$ \\
\hline \multirow[t]{3}{*}{ Bangladesh } & Shrimp (Penaeus monodon) & Improved extensive (brackish water ponds) & South-west/Khulna & $\begin{array}{l}\text { June } 2011 \text { to } \\
\text { November } 2011\end{array}$ & 24 & \\
\hline & $\begin{array}{l}\text { Shrimp and Prawn (Penaeus monodon } \\
\text { and Macrobrachium rosenbergii) }\end{array}$ & $\begin{array}{l}\text { Improved extensive concurrent with rice } \\
\text { (brackish/freshwater ponds) }\end{array}$ & South-west/Khulna & $\begin{array}{l}\text { June } 2011 \text { to } \\
\text { January } 2012\end{array}$ & 22 & $19^{\mathrm{f}}$ \\
\hline & Prawn (Macrobrachium rosenbergii) & $\begin{array}{l}\text { Improved extensive concurrent with rice }{ }^{\mathrm{b}} \\
\text { (freshwater ponds) }\end{array}$ & South-west/Khulna & $\begin{array}{l}\text { November and } \\
\text { December } 2011\end{array}$ & 20 & \\
\hline \multirow[t]{2}{*}{ China } & Tilapia (Oreochromis niloticus) & $\begin{array}{l}\text { Intensive and semi-intensive polyculture } \\
\text { (freshwater ponds) }{ }^{c}\end{array}$ & South-east/Maoming & $\begin{array}{l}\text { August and } \\
\text { September } 2011\end{array}$ & 25 & 5 \\
\hline & Shrimp (Litopenaeus vannamei) & $\begin{array}{l}\text { Intensive monoculture and polyculture } \\
\text { (brackish water ponds) }\end{array}$ & South-east/Zhanjiang & October 2011 & 30 & 5 \\
\hline \multirow[t]{2}{*}{ Thailand } & Tilapia (Oreochromis niloticus) & $\begin{array}{l}\text { Intensive and semi-intensive monoculture } \\
\text { and polyculture (freshwater ponds) }{ }^{\mathrm{e}}\end{array}$ & $\begin{array}{l}\text { Central/Suphanburi, and Nakhon } \\
\text { Pathom; East/Chachoengsao }\end{array}$ & $\begin{array}{l}\text { September } 2011 \text { to } \\
\text { March } 2012\end{array}$ & 31 & 5 \\
\hline & Shrimp (Litopenaeus vannamei) & $\begin{array}{l}\text { Intensive monoculture } \\
\text { (brackish water ponds) }\end{array}$ & $\begin{array}{l}\text { East/Chachoengsao and } \\
\text { Chanthaburi; South/Surat Thani }\end{array}$ & $\begin{array}{l}\text { October and } \\
\text { December } 2011\end{array}$ & 34 & 4 \\
\hline \multirow[t]{2}{*}{ Vietnam } & Catfish (Pangasianodon hypophthalmus) & $\begin{array}{l}\text { Intensive monoculture } \\
\text { (freshwater ponds) }\end{array}$ & $\begin{array}{l}\text { South/An Giang Province, Can Tho, } \\
\text { Dong Thap and Tra Vinh }\end{array}$ & $\begin{array}{l}\text { October } 2011 \text { to } \\
\text { February } 2012\end{array}$ & 32 & 9 \\
\hline & Shrimp (Penaeus monodon) & $\begin{array}{l}\text { Intensive and semi-intensive monoculture } \\
\text { (brackish water ponds) }\end{array}$ & South/Soc Trang and Bac Lieu & $\begin{array}{l}\text { December } 2011 \text { to } \\
\text { February } 2012\end{array}$ & 34 & 9 \\
\hline Total & & & & & 252 & 56 \\
\hline
\end{tabular}

a For a definition of the production systems see Murray et al. (2013).

b Tipically co-cultured with fish species (e.g. Hypophthalmichthys molitrix, Catla catla, Labeo rohita).

c All the interviewed farms cultured tilapia in combination with carps.

d The $27 \%$ of the interviewed farms combined the culture of shrimps with pompano (Trachinotus ovatus), mud crab (Scylla serrata) or prawns (Macrobrachium rosenbergii).

e The $61 \%$ of the interviewed farms cultured tilapia in combination with carps.

${ }^{\mathrm{f}}$ The records obtained from the farm supply shops in Bangladesh could not be exclusively attributed to specific species as they are produced in the same area.

representation of different aquaculture practices with a wide geographical spread within the study areas. Interviews were also carried out with staff managing aquaculture farm supply shops, co-located in the areas where the farms were situated, thereby being likely points of purchase for those farmers. The objectives of these interviews were: i) to be used as a validation step for chemicals that may have been under reported, ii) to build a chemical sales inventory to facilitate triangulation of the information provided by the farmers, and iii) to collect information on recommended dosages displayed on product labels. The characteristics of the surveyed aquaculture farm groups, geographical areas, dates of the interviews as well as number of farms and farm supply shops interviewed are detailed in Table 1.

The interviews with the grow-out farmers were conducted using structured questionnaires by local staff members experienced with aquaculture and with previous training in collection of chemical use data. The questionnaire comprised three sections: i) respondent characteristics, ii) farm characteristics and management practices, and iii) chemical use. For each of the veterinary compounds, feed additives and probiotic products used, information was collected with regards to: percentage of the main active ingredient(s) in the formulation used, application purposes and methods, dosage, pond water depth and cultured species biomass at the time of application, treatment duration, and average number of treatments per culture cycle.

\subsection{Data analysis}

\subsubsection{Compound classification}

The chemical and biological products were classified into five categories: i) antibiotics, ii) disinfectants, iii) parasiticides, iv) feed additives and plant extracts, and iv) probiotics. The parasiticide group also included compounds with biocidal properties (e.g. insecticides), used to kill unwanted organisms entering the aquaculture production systems with the inflow water. The main active ingredient(s) in each of the reported products was often recorded for antibiotics, disinfectants and parasiticides. When it was not available, it was identified by searching the reported product name in the sales inventories, and/or by cross checking with published literature. Products in the category of feed additives and plant extracts were classified as amino acids, herbs, minerals, polysaccharides and vitamins. However, due to the complexity of these formulations, the active ingredients were not further identified. For the same reason, the bacterial composition of the probiotic formulations was only qualitatively described.

\subsubsection{Comparison of reported and recommended dosages}

Reported dosages of antibiotic, disinfectant and parasiticide compounds were compared with recommended dosages. As farmers typically report dosages in mass of formulated product per area unit, the reported dosages were recalculated into standard dosage units (e.g. mg a.i. $\mathrm{L}^{-1}$, for compounds applied directly to water, or $\mathrm{mg} \mathrm{kg}^{-1}$ body weight of cultured organism, for compounds applied mixed with feed) and compared with the recommended dosages recorded from the labels of the products sold in the farm supply shops. Where the recommended dosages were unavailable, additional information on dosages was obtained from the literature (e.g., Arthur et al., 2000; Noga, 1996).

\subsubsection{Calculation of chemical mass inputs}

The chemical mass applied per average tonne of harvested produce in each farm group was calculated for each active ingredient in the antibiotics, disinfectants and parasiticides categories, for each product class in the feed additives and plant extracts category (i.e., amino acids, herbs, minerals, polysaccharides, vitamins and other feed additives), and for probiotics. This was done by calculating the mass applied of each chemical or product relative to production for each individual farm, and multiplying this value by the frequency of farmers that reported their use within the farm group. The methodology used for the calculation of the chemical or product mass used relative to production for each individual farm is described in the Supplemental Material. The calculated chemical mass applied was compared with literature data available for other aquaculture (salmon) and non-aquaculture commodities. 


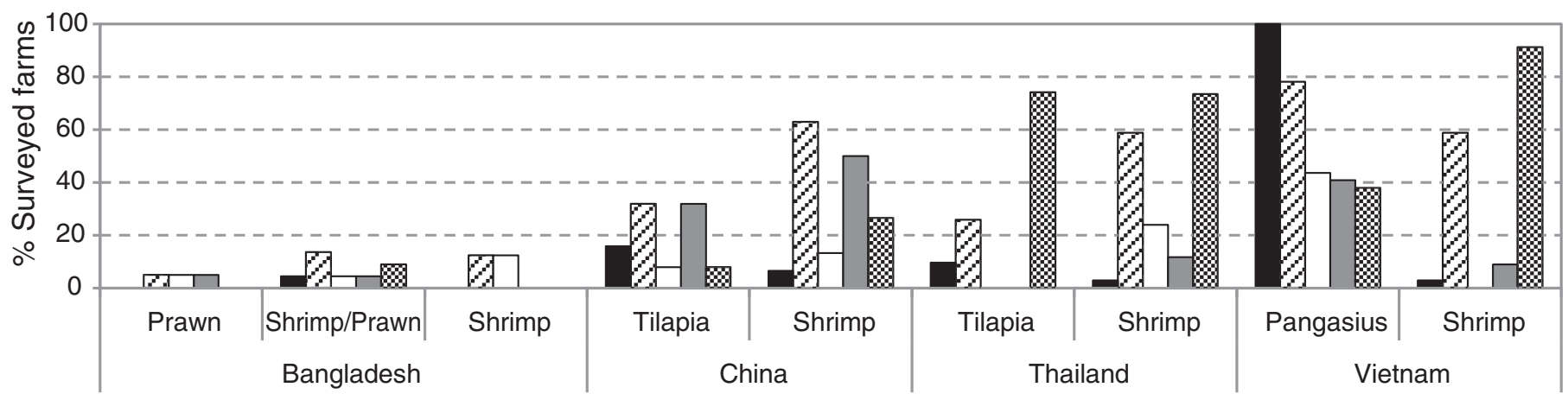

- Antibiotics $\boxminus$ Disinfectants $\square$ Parasiticides $\square$ Feed additives and plant extracts $\otimes$ Probiotics

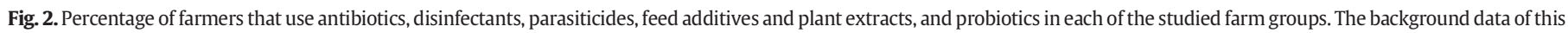
figure is provided as Supplemental Material (Table S1).

\subsubsection{Multivariate analysis}

Multivariate analyses were performed in order to assess the differences in active ingredients and chemical categories of compounds used among the studied farm groups. A dataset containing all the chemicals reported (dependent variables) was used to test the differences between different aquaculture farm groups (independent variables) in their chemical use practices. Multivariate analyses were also used to explore correlations between the respondent and farm characteristics, and the reported differences in chemical use at farm level. Specific chemical use datasets (dependent variables) for each of the studied farm groups were prepared in order to test the significance of each of the 16 descriptive parameters (independent variables) shown in Table 4 on the prevalence of chemical use. These 16 parameters were selected considering their potential to influence chemical and biological product management practices. Significance of the correlation between the independent variables and the variance in the chemical use datasets was tested by performing 499 Monte Carlo permutations by Redundancy Analysis (RDA) using the CANOCO 5 software package (Ter Braak and Smilauer, 2012). The correlation of the tested independent variable was considered significant when $p \leq 0.05$, and marginally significant when $0.05<p<0.1$. Individual biplots were constructed for each chemical use dataset including only those independent variables that resulted in significant or marginally significant correlations.

\section{Results}

\subsection{Chemical use in grow-out farms}

\subsubsection{Antibiotics}

The studied farms reported use of a total of 20 different antibiotic compounds. The percentage of shrimp farms that reported to use antibiotics in Thailand (2.9\%), Vietnam (2.9\%) and China (6.7\%) and the percentage of tilapia farms that reported to use antibiotics in Thailand (9.7\%) and China (16\%) markedly contrast with the frequency of use in the Vietnamese Pangasius farms (100\%) (Fig. 2; Table 2). The use of antibiotics in Bangladesh was only reported in one out of the 66 interviewed farms. Oxytetracycline, amoxicillin, florfenicol and enrofloxacin were reported in at least two countries. Overall, a maximum of two antibiotics were reported to be applied on any individual farm, with the exception of Pangasius farms in Vietnam. Here, 17 different antibiotic compounds belonging to 10 different antibiotic classes were used (penicillins, aminoglycosides, cephalosporins, quinolones, tetracyclines, amphenicols, polymyxin, diaminopyrimidines, rifamycins and sulfonamides), with enrofloxacin (69\% of farmers used it), florfenicol (63\%), sulfamethoxazole potentiated with trimethoprim (44\%), and doxycycline (34\%) being the most common ones (Fig. 3). Pangasius farmers reported use of three different antibiotics on average, and $10 \%$ of the interviewed farms reported use of five or six different antibiotics. It must be noted, however, that some antibiotic formulations used by Pangasius farmers contained a mix of two different active ingredients (sulfadimethoxine and ormetoprim; sulfamethoxazole and trimethoprim; apramycin and levofloxacin). In all cases, antibiotics were reported to be applied once a day mixed with feed for a period ranging between three and eight days. Most farmers reporting antibiotic use applied them to treat disease outbreaks, and only $5 \%$ of cases reported prophylactic use.

\subsubsection{Disinfectants}

Fifteen different disinfectants were reported to be applied for water disinfection and disease prevention (89\% of the reported applications), as disease treatment (10\%), and to disinfect equipment used during aquaculture operations (1\%). Disinfectants were most commonly used

Table 2

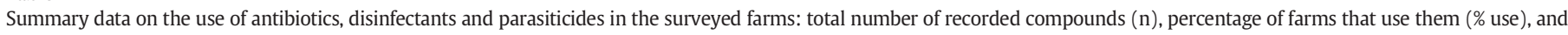
number of compounds used per farm ( $\mathrm{n}$ per farm; median, minimum-maximum).

\begin{tabular}{|c|c|c|c|c|c|c|c|c|c|c|c|c|c|}
\hline & & \multicolumn{3}{|c|}{ Antibiotics } & \multicolumn{3}{|c|}{ Disinfectants } & \multicolumn{3}{|c|}{ Parasiticides } & \multicolumn{3}{|c|}{ Total } \\
\hline & & $\mathrm{n}$ & $\%$ use & $\mathrm{n}$ per farm & $\mathrm{n}$ & $\%$ use & n per farm & $\mathrm{n}$ & $\%$ use & $\mathrm{n}$ per farm & $\mathrm{n}$ & $\%$ use & n per farm \\
\hline \multirow[t]{3}{*}{ Bangladesh } & Prawn & 0 & 0 & $0(0-0)$ & 1 & 5.0 & $0(0-1)$ & 1 & 5.0 & $0(0-1)$ & 2 & 10 & $0(0-1)$ \\
\hline & Shrimp/Prawn & 1 & 4.5 & $0(0-1)$ & 2 & 14 & $0(0-1)$ & 2 & 4.5 & $0(0-2)$ & 5 & 14 & $0(0-4)$ \\
\hline & Shrimp & 0 & 0 & $0(0-0)$ & 2 & 13 & $0(0-2)$ & 1 & 13 & $0(0-1)$ & 3 & 17 & $0(0-2)$ \\
\hline \multirow[t]{2}{*}{ China } & Tilapia & 2 & 16 & $0(0-1)$ & 5 & 32 & $0(0-1)$ & 2 & 8.0 & $0(0-2)$ & 9 & 44 & $0(0-3)$ \\
\hline & Shrimp & 2 & 6.7 & $0(0-1)$ & 8 & 63 & $1(0-2)$ & 4 & 13 & $0(0-3)$ & 14 & 63 & $1(0-4)$ \\
\hline \multirow[t]{2}{*}{ Thailand } & Tilapia & 2 & 9.7 & $0(0-1)$ & 3 & 26 & $0(0-1)$ & 0 & 0 & $0(0-0)$ & 5 & 29 & $0(0-2)$ \\
\hline & Shrimp & 2 & 2.9 & $0(0-2)$ & 6 & 59 & $1(0-3)$ & 4 & 24 & $0(0-2)$ & 11 & 79 & $1(0-3)$ \\
\hline \multirow[t]{2}{*}{ Vietnam } & Pangasius & 17 & 100 & $3(1-6)$ & 6 & 78 & $2(0-3)$ & 3 & 44 & $0(0-2)$ & 26 & 100 & $6(1-9)$ \\
\hline & Shrimp & 1 & 2.9 & $0(0-1)$ & 5 & 59 & $1(0-4)$ & 0 & 0 & $0(0-0)$ & 6 & 68 & $1(0-4)$ \\
\hline
\end{tabular}




\section{a. Bangladesh}

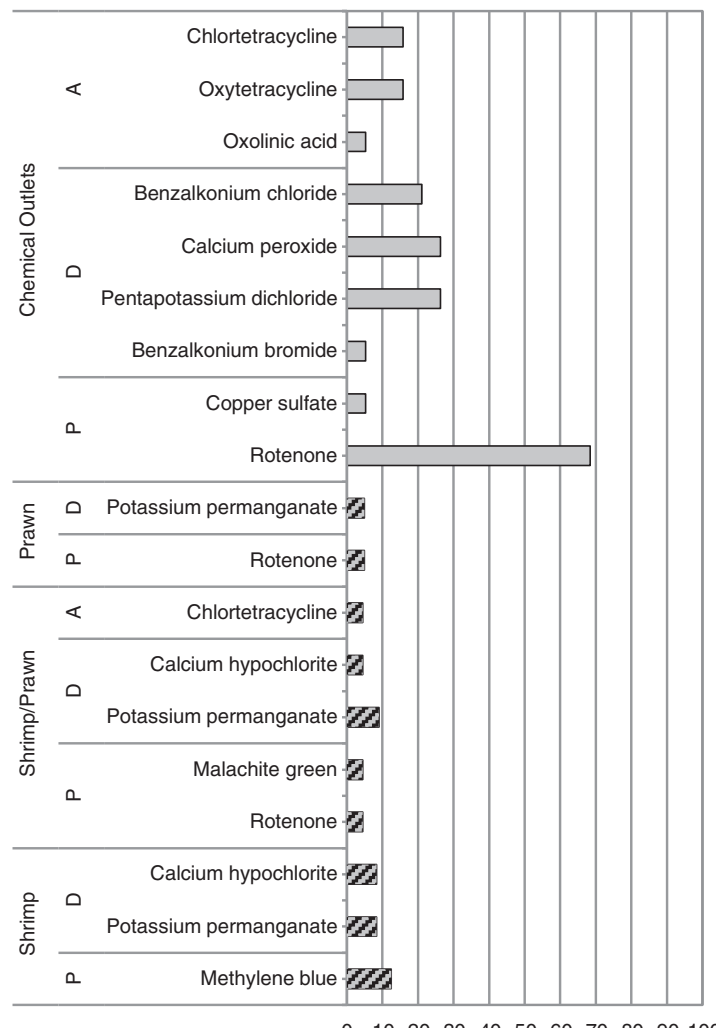

\section{Thailand}

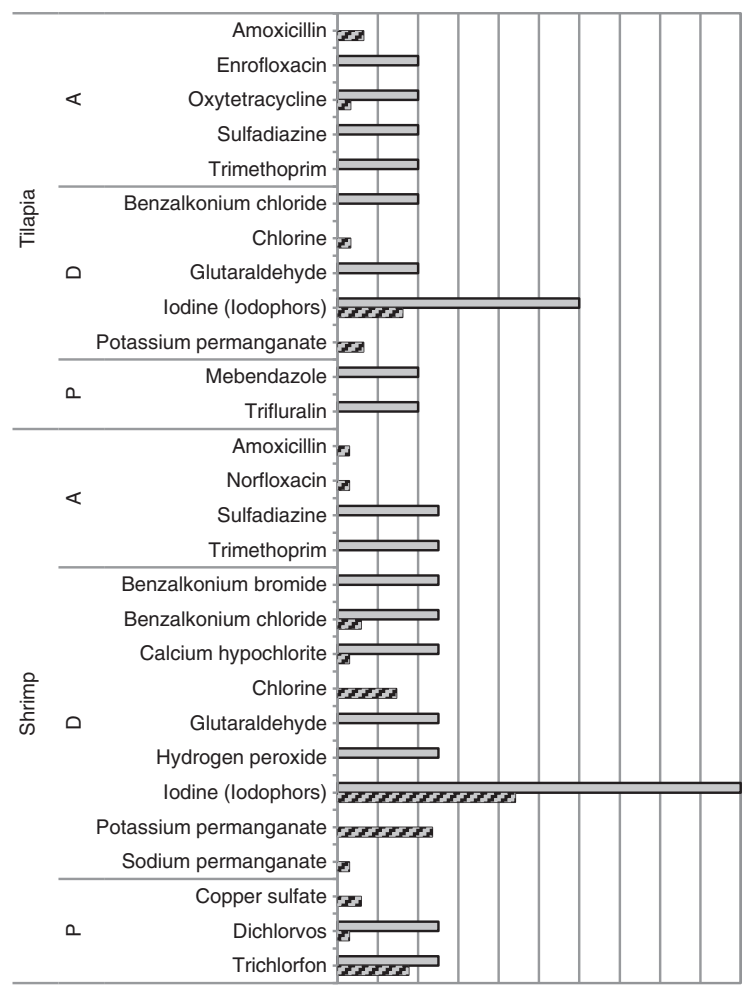

$0 \quad 10 \quad 20 \quad 3040 \quad 50 \quad 60 \quad 70 \quad 80 \quad 90100$

$\square \%$ of outlets that sell it

\section{b. China}

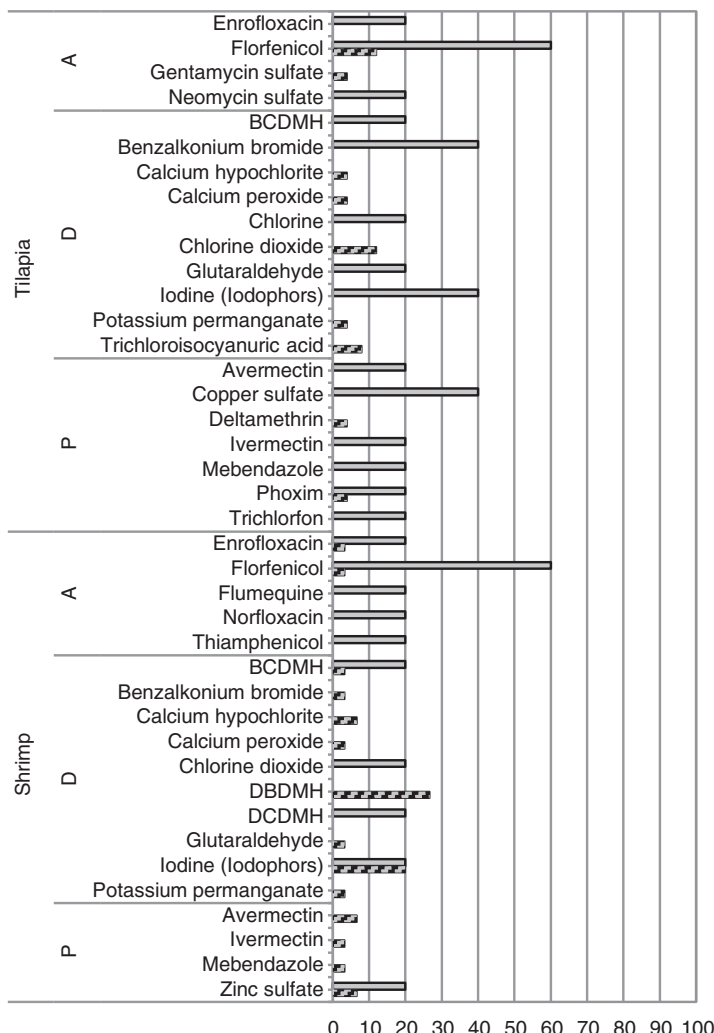

\section{d. Vietnam}

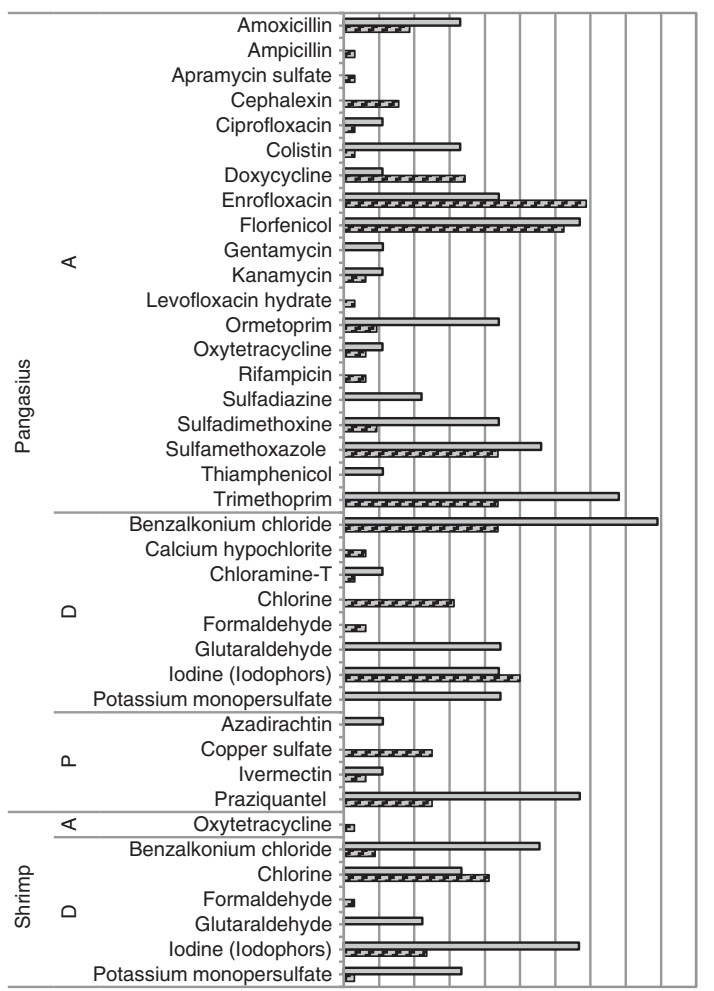

$0 \quad 102030405060708090100$

$\%$ of surveyed farms that use it

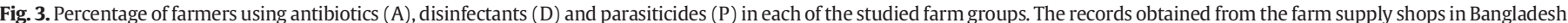

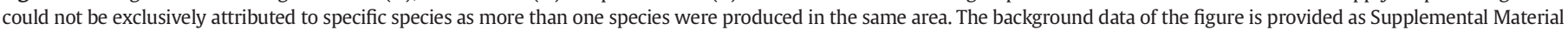
(Table S2,S3). (BCDMH: 1-Bromo-3-chloro-5,5-dimethylhydantoin; DBDMH: 1,3-Dibromo-5,5-dimethylhydantoin; DCDMH: 1,3-Dichloro-5,5-dimethylhydantoin). 
Table 3

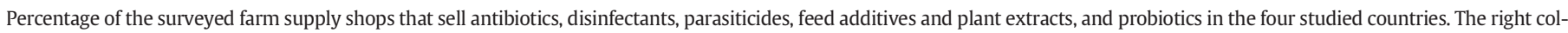
umn shows the compounds available in the surveyed shops that were not reported by the interviewed farmers.

\begin{tabular}{|c|c|c|c|c|c|c|c|}
\hline & & $\begin{array}{l}\text { Antibiotics } \\
(\%)\end{array}$ & $\begin{array}{l}\text { Disinfectants } \\
\text { (\%) }\end{array}$ & $\begin{array}{l}\text { Parasiticides } \\
\text { (\%) }\end{array}$ & $\begin{array}{l}\text { Feed additives and } \\
\text { plant extracts (\%) }\end{array}$ & $\begin{array}{l}\text { Probiotics } \\
(\%)\end{array}$ & Chemicals not reported by the surveyed famers \\
\hline Bangladesh & $\begin{array}{l}\text { Shrimp } \\
\text { and Prawn }\end{array}$ & 16 & 63 & 74 & 37 & 26 & $\begin{array}{l}\text { A: oxytetracycline, oxolinic acid; D: benzalkonium choride, benzalkonium } \\
\text { bromide, calcium peroxide, pentapotassium dichloride }\end{array}$ \\
\hline \multirow[t]{2}{*}{ China } & Tilapia & 80 & 40 & 40 & 100 & 100 & $\begin{array}{l}\text { A: enrofloxacin, neomycin sulfate; D: BCDMH, benzalkonium bromide, } \\
\text { chlorine, glutaraldehyde, iodine; P: avermectins, copper sulfate, } \\
\text { mebendazole }\end{array}$ \\
\hline & Shrimp & 60 & 80 & 40 & 100 & 100 & A: Flumequine, norfloxacin, thiamphenicol; D: chlorine dioxide, DCDMH \\
\hline \multirow[t]{2}{*}{ Thailand } & Tilapia & 40 & 60 & 20 & 60 & 100 & $\begin{array}{l}\text { A: enrofloxacin, sulfadiazine, trimethoprim; benzalkonium chloride, } \\
\text { glutaraldehyde; } \\
\text { P: mebendazole, trifluralin }\end{array}$ \\
\hline & Shrimp & 25 & 100 & 25 & 0 & 100 & $\begin{array}{l}\text { A: sulfadiazine, trimethoprim; D: benzalkonium bromide, glutaraldehyde, } \\
\text { hydrogen peroxide }\end{array}$ \\
\hline \multirow[t]{2}{*}{ Vietnam } & Pangasius & 89 & 100 & 78 & 56 & 78 & $\begin{array}{l}\text { A: gentamycin, sulfadiazine, thiamphenicol; D: glutaraldehyde, potassium } \\
\text { monopersulfate; } \\
\text { P: azadirachtin }\end{array}$ \\
\hline & Shrimp & 0 & 100 & 0 & 44 & 100 & D: glutaraldehyde \\
\hline
\end{tabular}

A: antibiotics; D: disinfectants; P: parasiticides; BCDMH: 1-Bromo-3-chloro-5,5-dimethylhydantoin; DCDMH: 1,3-Dichloro-5,5-dimethylhydantoin.

among Pangasius farmers (78\% of farms), which were applied regularly to the pond water to control bacterial proliferations, followed by shrimp farmers of China (63\%), Thailand (59\%) and Vietnam (59\%) (Fig. 2; Table 2). The majority of the disinfectant applications done by these shrimp farmers were done for disease prevention, being applied directly to water during the culture cycle (65\%) or prior to stocking (14\%), and only $11 \%$ of the reported disinfectant applications were done to treat disease outbreaks. Overall, the most commonly used disinfectants were single doses of iodine solutions (iodophors such as povidone-iodine), chlorine and chlorine-releasing compounds (benzalkonium chloride, calcium hypochlorite), and potassium permanganate (Fig. 3), with intervals between applications ranging from seven days to months.

\subsubsection{Parasiticides}

A total number of 13 compounds were found to be used to treat (external and internal) parasite and fungal infections in the cultured species, and to kill unwanted organisms in the culture ponds. There were marked differences in compounds used and application purposes among countries and species. The highest frequency of application was found for the Pangasius farms (44\% of the farms applied parasiticides) (Fig. 2; Table 2). Treatments with copper sulfate (25\%) applied directly to the pond water and in-feed medications of praziquantel (25\%) were the most common parasiticide treatments, followed by in-feed applications of ivermectin (6.3\%) (Fig. 3). About one fourth of the surveyed shrimp farmers of Thailand used the insecticides trichlorfon and/or dichlorvos (21\%), or copper sulfate $(6 \%)$, for killing unwanted organisms entering the ponds with the in-flow water during pond preparation prior to stocking. In-feed medications with avermectins and/or water treatments with fungicides (mebendazole and zinc sulfate) were reported to be applied in 13\% of the surveyed shrimp farms in China, and the fungicide methylene blue was used in 13\% of the shrimp farms in Bangladesh (Fig. 3).

\subsubsection{Feed additives and plant extracts}

Feed additives and plant extracts, directly applied to the water or mixed with feeds, were predominantly used in Chinese shrimp farms (50\% of farms), Vietnamese Pangasius farms (41\%), Chinese tilapia farms (32\%) (Fig. 2). Of the feed additives used in Chinese shrimp farms, the most common ones were vitamin premixes (38\%), amino acids (24\%), medicinal herbs and root extracts with antibacterial

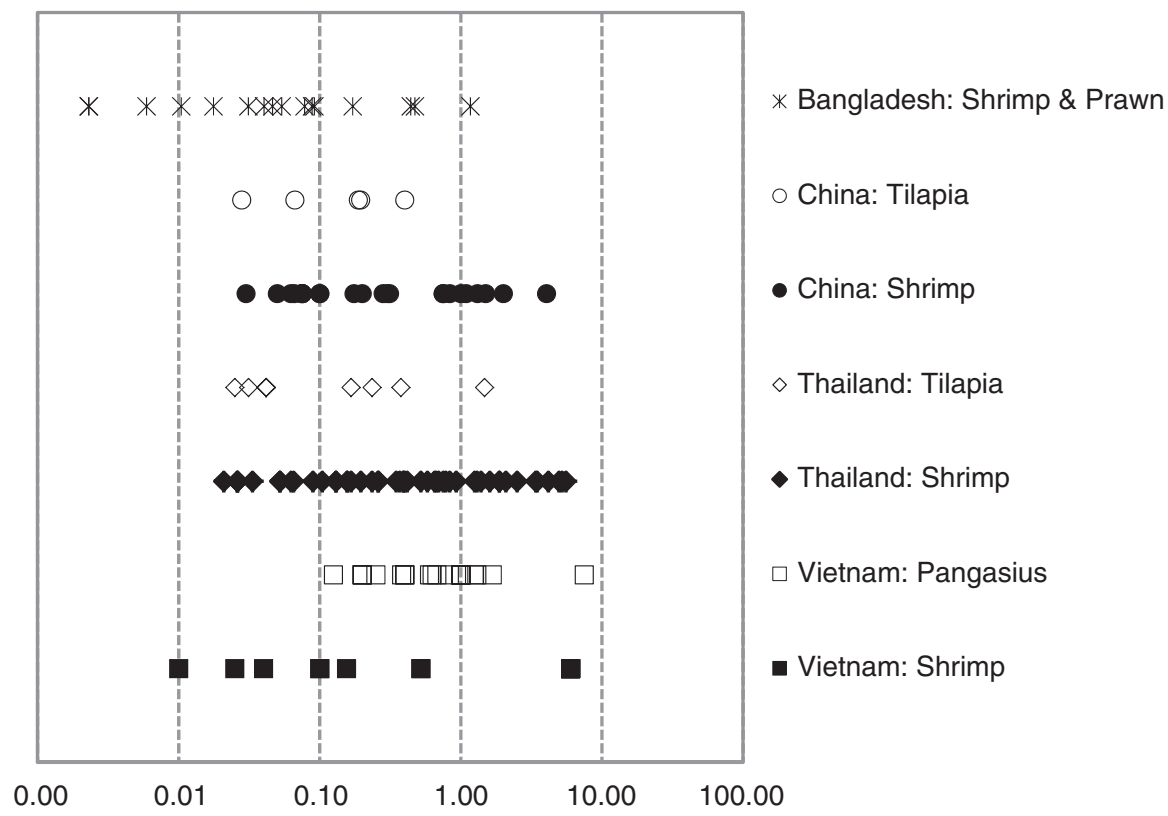

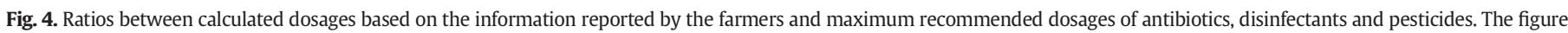
only displays the data entries for which enough information was available to calculate the actual applied dosages. 
properties such as Artemisia annua, Rheum rhabarbarum, Radix curcumae and Radix isatidis (22\%), as well as polysaccharides (11\%). Pangasius farmers used predominantly herb extracts (61\%) (e.g. Combretum dasystachyum Kurz) for pond water disinfection and feed supplements such as vitamin premixes (28\%), amino acids (11\%), and polysaccharides (11\%). Chinese tilapia farmers only reported the use of medicinal herbs (54\%) for disease treatment and mineral premixes (46\%) as feed additives.

\subsubsection{Probiotics}

The use of probiotics was found to be highest in Vietnamese shrimp farms (91\%), followed by the tilapia (74\%) and shrimp (74\%) farms in Thailand, Vietnamese Pangasius farms (38\%), shrimp farms in China (27\%), concurrent shrimp-prawn farms in Bangladesh (9\%) and Chinese tilapia farms (8\%) (Fig. 2). Probiotics were not reported to be used in the surveyed prawn and shrimp farms in Bangladesh. The probiotic products applied included a broad variety of formulations such as photosynthetic bacteria (e.g. Rhodopseudomonas spp.), microorganisms for nutritional and enzymatic contribution to digestion (e.g. Bacillus spp. and yeasts), and bacteria for improving water quality (e.g. Nitrosomonas spp., Nitrobacter spp.). The main bacterial genera were normally listed on the labels, but the specific species and their concentration in the products were most often not declared. Of the interviewed farmers, $84 \%$ reported to apply the probiotic products directly to water in order to improve the water quality and to reduce stress in the cultured species; whereas the other $16 \%$ reported to apply probiotics mixed with feeds as a nutritional supplement to improve food digestibility and the health conditions of the cultured species.

\subsection{Chemicals sold in farm supply shops}

The percentage of the surveyed farm supply shops in which the different compound groups were available are shown in Table 3, and the availability of the different antibiotics, disinfectants or parasiticides in Fig. 3. Chemical compounds available in the supply shops that were not reported by the interviewed farmers ranged between 1 and 9 compounds per farm group (Table 3 ).

\subsection{Comparison of reported and recommended chemical application dosages}

The comparison between reported and recommended chemical application dosages for antibiotics, disinfectants and parasiticides is shown in Fig. 4 as ratios between reported and maximum recommended dosages. The majority (77\%) of the reported single application dosages fell below the maximum recommended application dosages (ratios below 1). Cases in which the reported dose exceeded the recommended dose by a factor of three or more (ratios above 3 ) were only reported in the shrimp farms in China $(n=1)$, Thailand $(n=6)$ and Vietnam ( $\mathrm{n}=7)$, and on a single Pangasius farm in Vietnam $(\mathrm{n}=1)$, accounting for $11 \%$ of the all the evaluated cases. These cases mainly corresponded to applications of chlorine or chlorine releasing compounds ( $80 \%$ of the cases) for disinfection during pond preparation.

\subsection{Chemical mass inputs}

The estimated amounts of each chemical class per average tonne of harvested produce are shown in Fig. 5, and the disaggregated data

\section{a. Chemical mass applied relative to production}

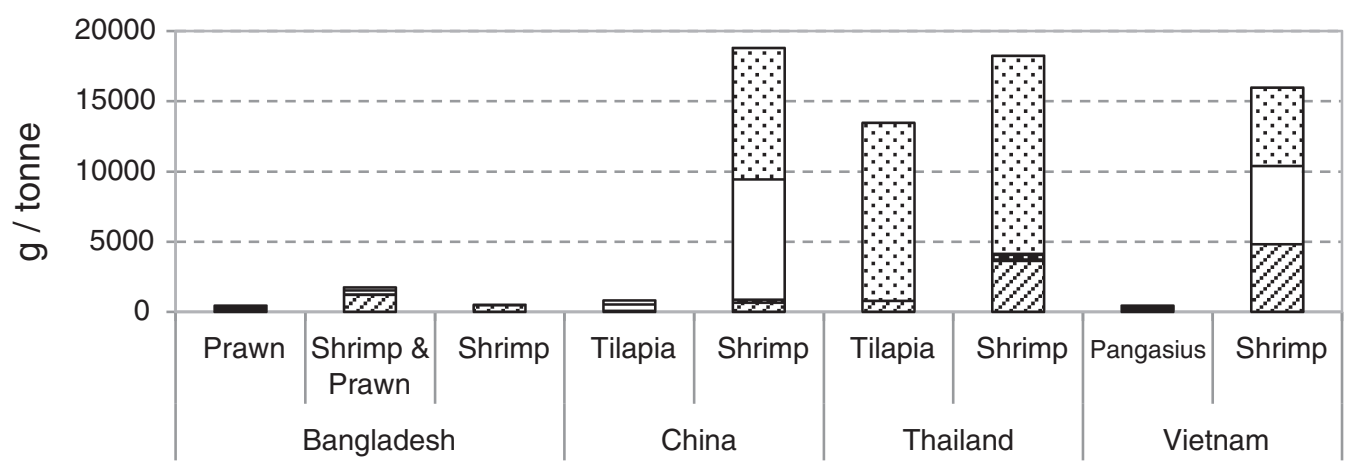

\section{b. Relative contribution of each chemical class to the total applied mass}

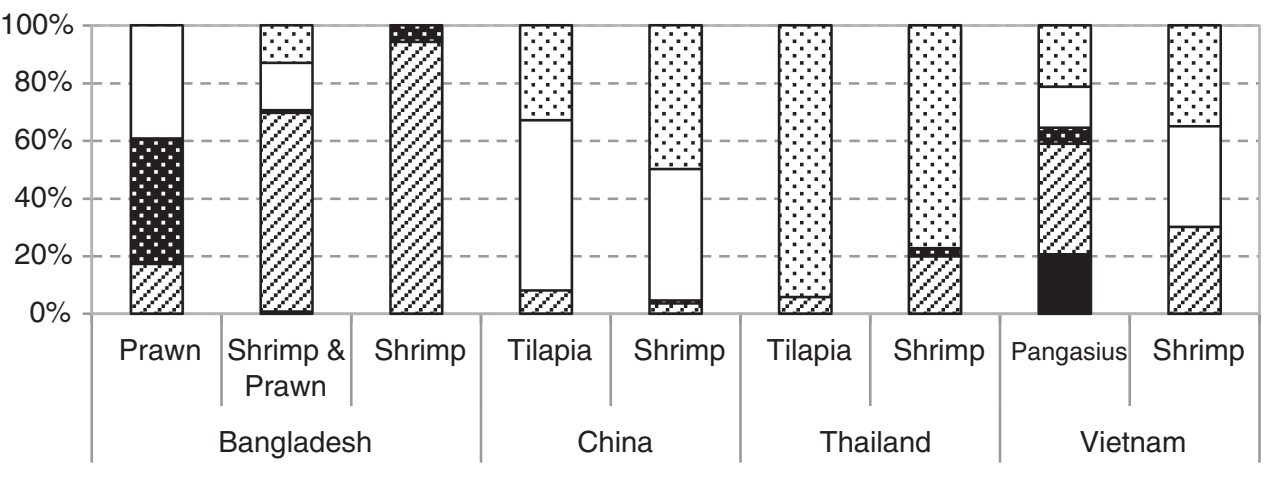

Antibiotics QDisinfectants Parasiticides $\square$ Feed additives and plant extracts @Probiotics

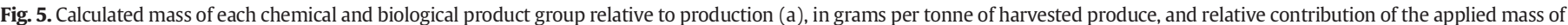

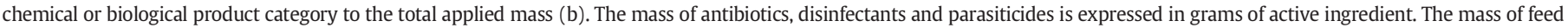

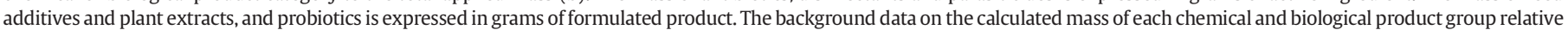
to production is provided as Supplemental Material (Table S4). 
(the amounts per active ingredient) for antibiotics, disinfectants, and parasiticides in Table S5. The highest mean amount of chemical inputs per tonne of harvested produce was calculated for the Chinese shrimp farms (18.8 $\mathrm{kg}$ tonne ${ }^{-1}$ harvested produce), followed by the Thai shrimp farms (18.2 $\mathrm{kg}$ tonne $\mathrm{e}^{-1}$ ), the Vietnamese shrimp farms (16.0 $\mathrm{kg}$ tonne $\left.\mathrm{e}^{-1}\right)$, and the Thai tilapia farms (13.5 $\mathrm{kg}_{\text {tonne }}{ }^{-1}$ ) (Table S4). The total chemical inputs was dominated by probiotics in Thai shrimp and tilapia production (77 and 94\%, respectively), and by probiotics, and feed additives and plant extracts, in the case of shrimp farms in China (50 and 46\%, respectively) and Vietnam (35\% for both compound categories). The largest amounts of veterinary compounds and biocides applied per tonne of harvested produce were calculated for the Vietnamese shrimp farms (4.8 $\mathrm{kg}_{\text {tonne }}{ }^{-1}$ harvested produce), followed by the Thai shrimp farms ( $4.1 \mathrm{~kg}$ tonne ${ }^{-1}$ harvested produce). In both cases this amount was dominated by disinfectants. Parasiticides contributed the most to the total applied mass in the Bangladeshi prawn farms (43\%), followed by the Bangladeshi shrimp farms, and the Vietnamese Pangasius farms (5.6\% for both). The marked difference observed in the Bangladeshi prawn farms, in respect to the other farm groups, can be explained by the low harvest yields and the high contribution of rotenone-containing plants and potassium permanganate (Table S5), which require high dosages for pond preparation and disease treatment in comparison to other (more toxic) parasiticides or biocidal ingredients (Table S2). The contribution of the antibiotics to the total chemical mass applied per tonne of harvested produce was markedly higher in the Vietnamese Pangasius farms (21\%) in comparison to the other studied farm groups (Fig. 5b). It was estimated that Vietnamese Pangasius farmers, on average, used $93 \mathrm{~g}$ of antibiotics per tonne of harvested fish (Table S4). The antibiotics that had the highest contribution to this amount were: sulfamethoxazole, cephalexin, amoxicillin, florfenicol and enrofloxacin (Table S5). In line with this, the antibiotic classes with the highest estimated application amount relative to harvested Pangasius biomass were, in decreasing order, sulfonamides, cephalosporins, penicillins, amphenicols, and quinolones (Table S6).

\subsection{Factors related to chemical use}

The results of the multivariate analyses showed that the use of chemicals by the different aquaculture farm groups was significantly different, as displayed in Fig. 6. Antibiotics, probiotics and disinfectants were the most prominent chemical groups. This confirms the relatively high use of antibiotics in the Vietnamese Pangasius farms in comparison to the other farm groups. It also shows a relatively high prevalence of probiotics use in the Vietnamese and Thai shrimp farms, and of disinfectants in the Vietnamese Pangasius farms, followed by the shrimp farms in Vietnam and Thailand.

The characteristics of the surveyed farms are shown in Table 4. The results from the Monte Carlo tests for each of the studied aquaculture farm groups, and the resulting biplots, are shown in the Supplemental Material (Tables S7 and S8, and Fig. S1). Although the number of chemicals reported to be applied in the surveyed Bangladeshi farms was very low, a trend was observed towards the use of a high number of compounds in the concurrent shrimp-prawn farms that reported the highest survival rates (survival shrimp: $p=0.01$; survival prawn: $p=0.04$ ). Also shrimp farms with higher reported stocking densities $(p=0.05)$ and longer crop durations $(p=0.05)$ tended to use a greater range of chemical inputs, and a similar trend was observed for larger prawn farms $(p=0.06)$, and those that reported the highest survival rates $(p=0.09)$.

In the surveyed Chinese tilapia farms, the frequencies of use of probiotics, feed additives and plant extracts, and parasiticides were marginally significantly higher for larger farms $(p=0.06)$, compared to smaller ones. For this farm group, higher frequencies were also positively correlated to the level of formal education of the respondents $(p=0.002)$. Farmers with university degrees were more likely to use them. In Chinese shrimp farms, a significant positive correlation was observed between the use of therapeutants, feed additives and probiotics, and increasing stocking densities $(p=0.04)$, annual yields $(p=0.02)$, and shrimp mortalities $(p=0.02)$. There was also a trend towards greater use of chemicals and biological products in intensive monoculture systems ( $p=0.07$ ), compared to polyculture systems.

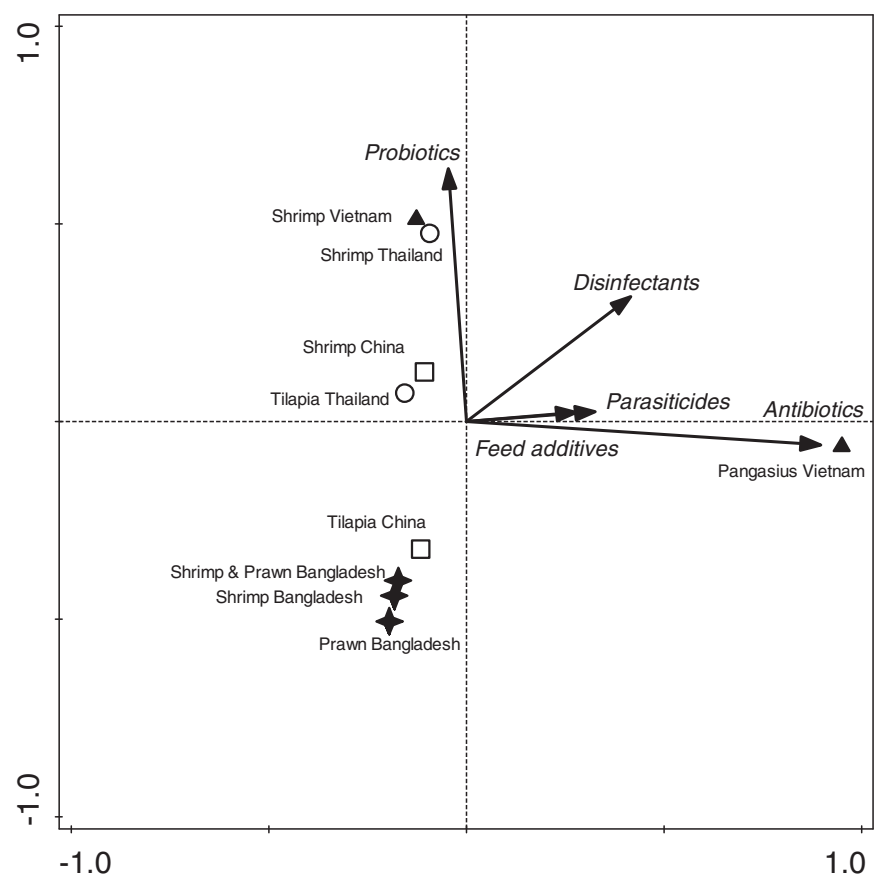

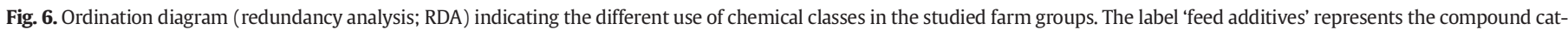

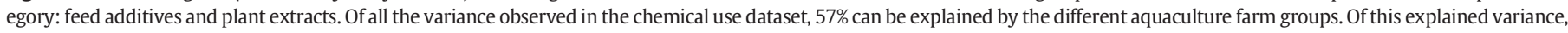

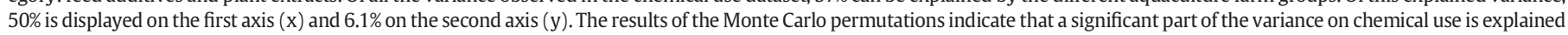
by the different aquaculture farm groups $(p=0.002)$. 


\begin{tabular}{|c|c|c|c|c|c|c|c|c|c|c|}
\hline & & \multicolumn{3}{|l|}{ Bangladesh } & \multicolumn{2}{|l|}{ China } & \multicolumn{2}{|l|}{ Thailand } & \multicolumn{2}{|l|}{ Vietnam } \\
\hline & & $\begin{array}{l}\text { Shrimp } \\
(\mathrm{n}=24)\end{array}$ & $\begin{array}{l}\text { Shrimp \& Prawn } \\
(\mathrm{n}=22)\end{array}$ & Prawn $(\mathrm{n}=20)$ & $\begin{array}{l}\text { Tilapia }(\mathrm{n}= \\
25)\end{array}$ & $\begin{array}{l}\text { Shrimp } \\
(\mathrm{n}=30)\end{array}$ & Tilapia $(\mathrm{n}=31)$ & Shrimp $(\mathrm{n}=34)$ & Pangasius $(\mathrm{n}=32)$ & Shrimp $(\mathrm{n}=34)$ \\
\hline \multirow[t]{3}{*}{$\begin{array}{l}\text { Respondent } \\
\text { characteristics }\end{array}$} & Role in the farm ${ }^{a}$ & $\mathrm{O}(17) ; \mathrm{M}(4) ; \mathrm{NR}(3)$ & $\begin{array}{l}\text { O (21); M (0); } \\
\text { NR (1) }\end{array}$ & $\mathrm{O}(18) ; \mathrm{M}(1) ; \mathrm{NR}(1)$ & $\begin{array}{l}\text { O (24); M (1); } \\
\text { NR (0) }\end{array}$ & $\begin{array}{l}\text { O (28); M (1); } \\
\text { NR (1) }\end{array}$ & $\mathrm{O}(20) ; \mathrm{M}(1) ; \mathrm{NR}(0)$ & $\mathrm{O}(27) ; \mathrm{M}(6) ; \mathrm{NR}(1)$ & $\mathrm{O}(25) ; \mathrm{M}(6) ; \mathrm{NR}(1)$ & $\mathrm{O}(31) ; \mathrm{M}(2) ; \mathrm{NR}(1)$ \\
\hline & General educational level ${ }^{\mathrm{b}}$ & $\begin{array}{l}\text { NO (1); PS (4); SS (19); } \\
\text { U (0); NR (0) }\end{array}$ & $\begin{array}{l}\text { NO (2); PS (3); } \\
\text { SS (17); U (2); } \\
\text { NR (0) }\end{array}$ & $\begin{array}{l}\text { NO (3); PS (5); } \\
\text { SS (11); U (0); } \\
\text { NR (1) }\end{array}$ & $\begin{array}{l}\text { PS (5); SS (17); } \\
\text { U (2); NR (1) }\end{array}$ & $\begin{array}{l}\text { PS (6); SS (19); } \\
\text { U (0); NR (0) }\end{array}$ & $\begin{array}{l}\text { PS (15); SS (12); } \\
\text { U (3); NR (1) }\end{array}$ & $\begin{array}{l}\text { PS (10); SS (7); } \\
\text { U (13); NR (4) }\end{array}$ & $\begin{array}{l}\text { PS (5); SS (18); U (9); } \\
\text { NR (0) }\end{array}$ & $\begin{array}{l}\text { NO (8); PS (12); SS (9); } \\
\text { U (5); NR (0) }\end{array}$ \\
\hline & Aquaculture education ${ }^{c}$ & $\begin{array}{l}\text { NO (20); WT (4); } \\
\text { U (0); NR (0) }\end{array}$ & $\begin{array}{l}\text { NO (17); WT (5); } \\
\text { U (0); NR (0) }\end{array}$ & $\begin{array}{l}\text { NO (14); WT (3); } \\
\text { U (0); NR (3) }\end{array}$ & $\begin{array}{l}\text { NO (20); WT (3); } \\
\text { U (1); NR (1) }\end{array}$ & $\begin{array}{l}\text { NO (19); WT (11); } \\
\text { U (0); NR (0) }\end{array}$ & $\begin{array}{l}\text { NO (9); WT (22); } \\
\text { U (0); NR (0) }\end{array}$ & $\begin{array}{l}\text { NO (8); WT (21); } \\
\text { U (5); NR (0) }\end{array}$ & $\begin{array}{l}\text { NO (17); WT (7); } \\
\text { U (8); NR (0) }\end{array}$ & $\begin{array}{l}\text { NO (15); WT (12); } \\
\text { U (1); NR (6) }\end{array}$ \\
\hline \multirow[t]{2}{*}{$\begin{array}{l}\text { Farm } \\
\text { geographical } \\
\text { location }\end{array}$} & Farm cluster ${ }^{\mathrm{d}}$ & $\begin{array}{l}\text { Cluster A (6); } \\
\text { Cluster B (6); } \\
\text { Cluster C (1); } \\
\text { Cluster D (6); } \\
\text { Cluster E (5) }\end{array}$ & $\begin{array}{l}\text { Cluster A (7); } \\
\text { Cluster B (8); } \\
\text { Cluster C ( } 7)\end{array}$ & $\begin{array}{l}\text { Cluster A (7); } \\
\text { Cluster B (6); } \\
\text { Cluster C (7) }\end{array}$ & $\begin{array}{l}\text { Cluster A (5); } \\
\text { Cluster B (7); } \\
\text { Cluster C (4); } \\
\text { Cluster D (2); } \\
\text { Cluster E (7) }\end{array}$ & $\begin{array}{l}\text { Cluster A (12); } \\
\text { Cluster B (6); } \\
\text { Cluster C (12) }\end{array}$ & $\begin{array}{l}\text { Cluster A (1); } \\
\text { Cluster B (13); } \\
\text { Cluster C (1); } \\
\text { Cluster D (8); } \\
\text { Cluster E (1); } \\
\text { Cluster F (7) }\end{array}$ & $\begin{array}{l}\text { Cluster A (2); } \\
\text { Cluster B (3); } \\
\text { Cluster C (5); } \\
\text { Cluster D (1); } \\
\text { Cluster E (1); } \\
\text { Cluster F (6); } \\
\text { Cluster G (3); } \\
\text { Cluster H (8); } \\
\text { Cluster I (5) }\end{array}$ & $\begin{array}{l}\text { Cluster A (4); } \\
\text { Cluster B (4); } \\
\text { Cluster C (6); } \\
\text { Cluster D (6); } \\
\text { Cluster E (1); } \\
\text { Cluster F (3); } \\
\text { Cluster G (2); } \\
\text { Cluster H (6) }\end{array}$ & $\begin{array}{l}\text { Cluster A (1); } \\
\text { Cluster B (1); } \\
\text { Cluster C (6); } \\
\text { Cluster D (6); } \\
\text { Cluster E (11); } \\
\text { Cluster F (9) }\end{array}$ \\
\hline & Province & Khulna (24) & Khulna (22) & Khulna (20) & Maoming (25) & Zhanjiang (30) & $\begin{array}{l}\text { Nakhon Phatom (17); } \\
\text { Chachoengsao (14) }\end{array}$ & $\begin{array}{l}\text { Chantaburi (10); } \\
\text { Surat Thani (18); } \\
\text { Chachoengsao (6) }\end{array}$ & $\begin{array}{l}\text { An Giang (16); } \\
\text { Dong Thap (9); } \\
\text { Can Tho (5); } \\
\text { Ben Tre (1); } \\
\text { Tra Vinh (1) }\end{array}$ & $\begin{array}{l}\text { Soc Trang (25); } \\
\text { Bac Lieu (9) }\end{array}$ \\
\hline \multirow{2}{*}{$\begin{array}{l}\text { Adopted } \\
\text { certification } \\
\text { schemes }\end{array}$} & 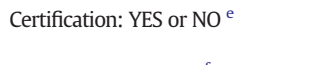 & NO (24); YES (0) & $\begin{array}{l}\text { NO (22); } \\
\text { YES }(0)\end{array}$ & $\begin{array}{l}\text { NO (20); YES } \\
(0)\end{array}$ & $\begin{array}{l}\text { NO (24); } \\
\text { YES (1) }\end{array}$ & $\begin{array}{l}\text { NO (30); } \\
\text { YES (0) }\end{array}$ & $\begin{array}{l}\text { NO (14); YES (11); } \\
\text { NR (6) }\end{array}$ & $\begin{array}{l}\text { NO (0); YES (33); } \\
\text { NR (1) }\end{array}$ & NO (27); YES (5) & NO (34); YES (0) \\
\hline & Certification scheme ${ }^{\mathrm{f}}$ & NO (24) & NO (24) & NO (24) & $\begin{array}{l}\text { NO (24); } \\
\text { PF (1) }\end{array}$ & NO (30) & NO (11); GAP (14) & $\begin{array}{l}\text { NO (0); GAP (26); } \\
\text { GAA/ACC/GAP (1); } \\
\text { GAP/CoC (4); } \\
\text { GAA/ACC/GAP/CoC } \\
\text { (1); CoC (1); NR (1) }\end{array}$ & $\begin{array}{l}\text { NO (23); PGGAP (4); } \\
\text { GGAP (5) }\end{array}$ & NO (34) \\
\hline \multirow[t]{4}{*}{$\begin{array}{l}\text { Farm } \\
\text { characteristics }\end{array}$} & Farm scale ${ }^{g}$ & S (9); M (9); L (6) & S (13); M (9); L (0) & $\begin{array}{l}\text { S (9); M (11); } \\
\text { L (0) }\end{array}$ & $\begin{array}{l}\text { S (15); M (8); } \\
\text { L (2) }\end{array}$ & $\begin{array}{l}\text { S (13); M (15); } \\
\text { L (2) }\end{array}$ & S (19); M (11); L (1) & S (13); M (14); L (7) & $S(15) ; M(11) ; L(6)$ & S(10); M (18); L (6) \\
\hline & Aquaculture production system ${ }^{\mathrm{h}}$ & IE (24) & $\mathrm{IE}(22)$ & $\mathrm{IE}(20)$ & IP (4); IL (21) & $\begin{array}{l}\operatorname{IM}(22) ; \operatorname{IP}(7) ; \\
\operatorname{SIP}(1)\end{array}$ & $\begin{array}{l}\text { SIM (12); } \\
\text { SIP (18); } \\
\text { IM (1) }\end{array}$ & $\operatorname{IM}(34)$ & $\operatorname{IM}(32)$ & $\begin{array}{l}\operatorname{IEA}(2) ; \operatorname{SIM}(21) \text {; } \\
\operatorname{IM}(11)\end{array}$ \\
\hline & Surface area $(\text { ha })^{i}$ & $14(0.2-79)$ & $0.5(0.1-1.1)$ & $0.4(0.2-1.0)$ & $3.3(0.3-19)$ & $3.2(0.2-22)$ & $4.4(0.3-22)$ & $16(1.0-75)$ & $2.9(0.2-11)$ & $2.7(0.7-11)$ \\
\hline & Number of grow-out ponds ${ }^{i}$ & 1 & 1 & 1 & $3.8(1.0-17)$ & $3.8(1.0-16)$ & $3.1(1.0-13)$ & $14(0.6-80)$ & $4.3(1.0-15)$ & $6.1(2.4-17)$ \\
\hline \multirow{4}{*}{$\begin{array}{l}\text { Farming } \\
\text { records }\end{array}$} & Crops per year ${ }^{\mathrm{i}}$ & 1 & 1 & $1.1(1.0-1.5)$ & $1.4(1.0-2.4)$ & $2.2(1.7-3.0)$ & $1.2(1.0-2.3)$ & $2.6(1.9-4.0)$ & $1.4(1.0-1.5)$ & $1.1(1.0-2.0)$ \\
\hline & Average crop duration (months) ${ }^{\mathrm{i}}$ & $3.0(2.5-4.7)$ & $\begin{array}{l}\text { Shrimp } 3.2(3.0-4.0) \text {; } \\
\text { Prawn } 6.9 \text { (4.0-12) }\end{array}$ & $6.3(5.0-8.5)$ & $6.2(3.6-12)$ & $3.0(2.1-3.8)$ & $7.9(4.7-12)$ & $3.5(2.7-5.1)$ & $7.3(6.0-8.9)$ & $5.3(3.0-7.1)$ \\
\hline & Stocking density (individuals $\left./ \mathrm{m}^{2}\right)^{\mathrm{i}}$ & $7.4(2.6-20.5)$ & $\begin{array}{l}\text { Shrimp } 3(0.6-9.0) \\
\text { Prawn 1.7 (0.2-4.4) }\end{array}$ & $2.8(0.9-5.7)$ & $3(1.8-4.5)$ & $154(26.7-465)$ & $2.5(0.3-7.0)$ & $64(38-104)$ & $52(24-88)$ & $25(7.6-44)$ \\
\hline & $\begin{array}{l}\text { Annual yield (tonnes/ha/crop) }{ }^{\mathrm{i}} \\
\text { Survival (\%) }{ }^{\mathrm{i}}\end{array}$ & $\begin{array}{l}\text { NA } \\
36(13-84)\end{array}$ & $\begin{array}{l}\text { NA } \\
\text { Shrimp 36 (7.0-77); } \\
\text { Prawn } 54 \text { (15-85) }\end{array}$ & $\begin{array}{l}\text { NA } \\
48(19-80)\end{array}$ & $\begin{array}{l}14.6(4.4-26) \\
89(78-100)\end{array}$ & $\begin{array}{l}11(1.4-32) \\
62(39-80)\end{array}$ & $\begin{array}{l}\text { NA } \\
57(40-85)\end{array}$ & $\begin{array}{l}\text { NA } \\
81(70-96)\end{array}$ & $\begin{array}{l}295(76-509) \\
77(61-88)\end{array}$ & $\begin{array}{l}\text { NA } \\
72(33-92)\end{array}$ \\
\hline
\end{tabular}

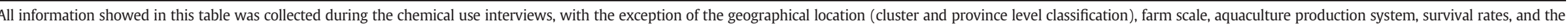
information on the categories of farm characteristics and farming records for the Thai farms, which was retrieved from the SEAT project Primary Survey (Murray et al., 2013).

a: Owner; M: Manager; NR: Not reported.

b NO: None; PS: Primary school; SS: Secondary school; U: University studies; NR: Not reported.

c NO: None; WT: Workshop or training course in aquaculture; U: University studies on aquaculture; NR: Not reported.

d Farm cluster classification performed according to Murray et al. (2013).

e NO: Do not belong to any certification scheme; YES: Belong to one or more certification schemes; NR: Not reported.

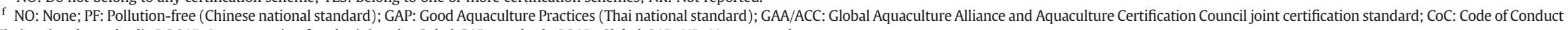
(Thai national standard); PGGAP: In preparation for obtaining the Gobal GAP standard; GGAP: Global GAP; NR: Not reported.

g S: Small; M: Medium; L: Large. For a description of the farm scale classification see Murray et al. (2013).

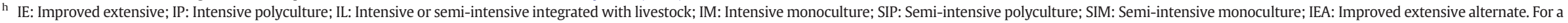
description of the production system categories see Murray et al. (2013).

${ }^{\mathrm{i}}$ Mean (95\% Confidence Interval); NA: Not available. 
The chemical use data for Thai tilapia farms reflects a tendency towards differences in active ingredients used in different provinces $(p=0.06)$, and a higher frequency of chemical use by farmers that had received formal training on aquaculture production $(p=0.04)$. For the surveyed shrimp farms in Thailand, farm scale was found to be significantly correlated with reported chemical use patterns ( $p=0.02$ ), indicating that large farms, compared to the medium and small scale farms, tended to use more biocidal compounds as preventive measure for pond preparation (trichlorfon, dichlorvos, copper sulfate). On the contrary, use of probiotics and disinfectants was more commonly reported for medium-scale farms, and use of antibiotics and feed additives was most common in small-scale farms. The certification schemes adopted by shrimp farmers in Thailand had a marginally significant correlation with the compound classes used by them $(p=0.06)$. This points towards a relationship between the large farms, certified with the Thai Code of Conduct $(\mathrm{CoC})$, and higher use of biocidal compounds.

The variance in the different active ingredients applied by the Pangasius surveyed farms could be significantly explained by the provincial distribution of the farms $(p=0.05)$, the adoption of the Global GAP certification scheme $(p=0.03)$, and the stocking density ( $p=0.01$ ). However, differences in compound classes used by different Pangasius farmers could only be marginally attributed to location (province) ( $p=0.08$ ) and the respondent's education level in aquaculture $(p=0.09)$. The latter indicating a link between no, or little, formal aquaculture training among farmers in the An Giang province, and high frequency of use of antibiotic compounds. None of the studied parameters resulted in significant effects on the chemical use reported by the shrimp famers in Vietnam, with only a marginal trend $(p=0.07)$ observed towards the highest use of disinfectants in the Soc Trang province, and the highest reported frequency of use of probiotics and feed additives in the Bac Lieu province.

\section{Discussion}

\subsection{Chemical use in the surveyed farm groups}

Sixty different veterinary medicinal ingredients were recorded including 26 antibiotics, 19 disinfectants and 15 parasticides. Based on the farm groups studied, semi-intensive and intensive shrimp production in China, Thailand and Vietnam were found to rely most heavily on chemical and biological product inputs per tonne of harvested produce, in comparison to the extensive shrimp and prawn systems of Bangladesh (Fig. 5a). Thus, a positive correlation was found between the estimated total amount of chemicals and biological products used by shrimp/prawn aquaculture farmers, and their production intensity. For shrimp farmers in Thailand, Vietnam and China, our results revealed relatively low frequencies of antibiotic use, while displaying more frequent use of disinfectant treatments (Table 2). This contrasts with the outcomes of similar surveys conducted during the last decade in shrimp farms in Thailand (Holmström et al., 2003) and Vietnam (Le and Munekage, 2004; Tu et al., 2006). Several factors that could explain these differences, and the apparent decline in the use of preventive and therapeutic antibiotic treatments in shrimp production, include: $i)$ the replacement of the black tiger shrimp (P. monodon), in Thailand and China, and nowadays starting to take place in Vietnam, by the white leg shrimp (L. vannamei), a species with higher growth rates and less vulnerable to specific diseases (Lebel et al., 2010); ii) the use of specific pathogen free (SPF) larvae; iii) the introduction of several biosecurity measures including the reduction in the occurrence of pathogens, parasites and predators by the regular use of several antibacterial agents and biocides for water (pre-)treatment and disinfection of the equipment and production systems; iv) the use of a wide range of prebiotic and probiotic formulations for improving the water quality and the health status of the cultured animals; v) the development of microbial resistance to several antibiotics; vi) the pressure by national and international organizations to reduce their use due to food safety reasons and potential market restrictions. In line with these results, notifications from the EU Rapid Alert System for Food and Feed (RASFF) on food safety standard violations from antibiotic residues on shrimp products from these three countries have seen a considerable reduction in the last five years (Murray et al., 2012).

Amongst the fish producing farm groups, tilapia farmers from Thailand reported the largest amount of chemical inputs relative to production (mainly consisting of probiotics), followed by tilapia farmers in China, and Pangasius farmers of Vietnam (Fig. 5a). The highest prevalence of veterinary compounds use was observed in Vietnamese Pangasius farms (Table 2, Fig. 5b). For this farm group, a total number of 32 different ingredients were recorded, including those reported by farmers and those available in the farm supply shops, with farmers reporting an average use of 6 different veterinary compounds. The percentage of antibiotic use, as well as the most commonly recorded active ingredients, are in accordance with the results of the survey performed by Phuong (2010) during 2008, suggesting that the antibiotic use has been stable during the last few years. Antibiotics applied to Pangasius are mainly used for treatment of bacillary necrosis and the red spot disease, which are reported to be caused by Edwardsiella ictaluri and Aeromonas spp., respectively. The regular application of antibiotics and the use of doses below the therapeutic effective dose has resulted on the development of bacterial resistance and a consequent loss on the efficacy of some antibiotics (Bartie et al., 2012; Dung et al., 2008, 2009). The prevalence of antibiotic resistant bacteria in Pangasius fish ponds and the potential horizontal gene transfer from fish pathogens and other aquatic bacteria to humans requires further attention by local authorities. Nowadays, there are a total of 28 antibiotic ingredients authorized for use in aquaculture in Vietnam (Tai, 2012), and this list must be revised with especial attention to their resistance potential, excluding antibiotics that are also used in human medicine (e.g. penicillins, cephalosporins or rifampicin). The use of biosecurity measures to prevent bacterial diseases becomes almost impossible in Pangasius ponds due to the high fish densities and the required high water exchange rates (Phan et al., 2009). Thus, the main alternative to extensive antibiotic use is the introduction of vaccines, as already done in the European salmon industry (Gudding, 2012). Research is currently dedicated to the development and testing of vaccines against Edwardsiella ictaluri, showing promissory results (Dung, 2011; Thinh et al., 2009).

The dataset generated through the interviews conducted in the farm supply shops was found to correspond reasonably well with the dataset generated in the farm interviews. Compound-specific discrepancies were not further investigated, as they could simply be related to the fact that farmers purchased their products in different shops or through feed retailers. The comparison between recommended dosages and those reported by the farmers demonstrates that there is no evidence to affirm that the surveyed aquaculture farmers overdose their cultured animals, but rather the opposite. In our study, exceeded recommended dosages were mainly attributed to chlorine and chlorine releasing compounds applied for pond disinfection prior to stocking in shrimp farms, and this could be explained by the different effectiveness of these compounds in presence of organic matter and the corresponding variable application dosages (Arthur et al., 2000).

Chemicals banned under national regulations in Bangladesh (BDOF, 2011), China (CMA, 2002), Thailand (Tukwinas, 2002) and Vietnam (VMARD, 2009), and major seafood importing countries, such as EU countries, United States, Canada and Japan (see Love et al., 2011) (such as chloramphenicol, nitrofurans, etc.), were generally not reported to be applied by the interviewed farmers, neither were they found to be available in the interviewed farm supply shops. The exception was the parasiticide/fungicide malachite green, which was reported to be applied in only one out of the 66 surveyed farms in Bangladesh, and is currently internationally banned for use in aquaculture due to its attributed carcinogenic properties (Srivastava et al., 2004). 
Fluoroquinolone antibiotics, which have been recently banned for application in aquaculture in the US and Canada, were reported to be applied in China, Thailand, and Vietnam, with a markedly higher frequency of application in the Vietnamese Pangasius farms (especially enrofloxacin). The high rate of associated veterinary drug violations of Vietnamese aquaculture products, particularly for catfish, in US, Japan and Canada (Love et al., 2011) has forced the Vietnamese government to ban the use of enrofloxacin and ciprofloxacin for use in aquaculture (VMARD, 2012). Hence, it is expected that their use will have recently diminished.

\subsection{Comparison with other food producing commodities}

The interviewed Pangasius farmers were found to use a wider range of antibiotic ingredients than salmon farmers in European countries, Chile and Canada (Table 5). However, the amount of antibiotics used per tonne of harvested Pangasius produce in Vietnam (93 g) did not exceed the most recent estimate for antibiotics used in Canadian salmon production, and is considerably lower than the most recently reported values for salmon production in Chile (Table 5). Estimated amounts of antibiotic used in the other farm groups investigated in the current study are well below the values reported for Pangasius production in Vietnam (Table S4), and are in the range of the most recently reported values for salmon production in Norway and United Kingdom (after the displacement of antibiotic treatments by vaccines). On the other hand, a study by Grave et al. (2010) showed that estimated amounts of antibacterial agents used in poultry and livestock production in European countries varies from 18 to $188 \mathrm{~g}$ a.i. tonne ${ }^{-1}$ of produced biomass. This suggests that the use of antibiotics in Pangasius production, and in all other presently studied aquaculture farm groups, fall short of the reported amounts for other important food-producing species. In comparison to the chemical use in salmon production, the surveyed aquaculture farmers, however, rely upon larger amounts of other antimicrobial agents for disinfecting ponds, water and equipment, and chemicals with biocidal properties, most commonly used for killing unwanted organisms entering the ponds with the in-flow water. The quantity of chemicals used to kill external parasites, worms, and fungal infestations (excluding other biocides) in our studied farm groups (Table S4), falls short, or is in the range of, the quantities used in salmon aquaculture (Table 5). A few exceptions, however, are concurrent shrimp-prawn farms and the shrimp farms in Bangladesh, and Pangasius farms in Vietnam. For these farm groups, the estimated amounts were one order of magnitude greater due to the application of fungicides, which require higher dosages in comparison to the antihelmintics and insecticides reportedly used in the other farm groups, and the parasiticide compounds traditionally used to control sea-lice infestations in salmon production (e.g. emamectin benzoate, deltamethrin, cypermethrin, hydrogen peroxide) (Bravo, 2012; Burridge et al., 2010).

\subsection{Factors influencing chemical use patterns}

The analysis of determinants on chemical use patterns indicated that the observed variability within the studied aquaculture farm groups cannot be explained by the same factor or group of factors (Table S7, S8). The farm characteristics influencing chemical use patterns were found to correspond with the culture intensity. For instance, the analysis showed a trend towards higher reported survival rates in the concurrent shrimp-prawn farms, and prawn farms that used them. This suggests that the introduction of chemical and biological treatments in these extensive systems, mainly as a preventive measure, could have contributed to increased survival (Fig. S1). On the other hand, the Chinese shrimp farms with intensive monoculture practices showed a tendency towards a greater reliance on disinfectants, antibiotics and probiotics (Fig. S1). This trend was negatively correlated to the survival rates (Fig. S1), suggesting that these farms might have reached a maximum in terms of stocking and production intensity, which could be related to the need to use antimicrobial and probiotic treatments in order to control disease outbreaks. Chemical use patterns in Thai shrimp farms, however, showed a clear correlation between the chemical groups used and the size of the farms (Table S7). Thus indicating that larger farmers with better investment possibilities, and well established aquaculture management practices, tend to use greater amounts of biocidal products during pond preparation as a preventive biosecurity measure instead of antibiotic or expensive probiotic treatments. In comparison to the Chinese shrimp farmers, Thai farmers generally held lower stocking densities (Table 4) and also used less chemicals for disease treatment. Interestingly, the province in which a farm was located was the only factor that showed a clear correlation with the type of active ingredient(s) used in all the farm groups evaluated (Table S8). This suggests that regional chemical marketing strategies as well as the recommendations by fellow farmers are key drivers explaining variability in chemical use practices. On the other hand, the results of this study show that the application of certification schemes in the surveyed tilapia and Pangasius farms does not imply a reduction on the use of antibiotic or other environmentally hazardous compounds in comparison to non-certified farms (Table S7). Conversely, large-scale shrimp farmers of Thailand that obtained the Thai Code of Conduct certification showed a trend towards more frequent use of biocidal compounds during pond

Table 5

Quantities of chemicals used in Atlantic salmon aquaculture ( $\mathrm{g}$ a.i. tonne $\mathrm{e}^{-1}$ harvested fish)

\begin{tabular}{|c|c|c|c|c|}
\hline Country & Compound class (year) & Mean (min-max) & No. of compounds & Reference \\
\hline \multirow[t]{7}{*}{ Norway } & Antibiotics (1980-1989) & $464(163-864)$ & NA & $\operatorname{NIPH}(2009)^{a}$ \\
\hline & Antibiotics (1990-1999) & $71.6(1.28-257)$ & NA & \\
\hline & Antibiotics (2000-2011) & $1.42(0.54-2.29)$ & 4 & \\
\hline & Sea-lice treatments (2001-2008) & $0.20(0.15-0.26)$ & 5 & \\
\hline & Antihelmintics (2001-2008) & $0.31(0.10-0.72)$ & 2 & \\
\hline & Fungicides (2001-2008) & $0.71(0.52-0.82)$ & 2 & \\
\hline & Sum all parasiticides (2001-2008) & $1.21(0.87-1.43)$ & 9 & \\
\hline \multirow[t]{4}{*}{ Chile } & Antibiotics (1999-2003) & $252(210-280)$ & 7 & Bravo (2012) \\
\hline & Antibiotics (2007-2008) & $580(640-520)$ & 7 & \\
\hline & Parasiticides (1999-2003) & $0.22(0.14-0.28)$ & 4 & \\
\hline & Parasiticides (2007-2008) & $1.20(0.88-1.52)$ & 3 & \\
\hline \multirow[t]{2}{*}{ UK } & Antibiotics (2007) & 11.7 & NA & Burridge et al. (2010) \\
\hline & Sea-lice treatments (2007) & 1.50 & NA & \\
\hline \multirow[t]{2}{*}{ Canada } & Antibiotics (2007) & 175 & NA & Burridge et al. (2010) \\
\hline & Sea-lice treatments (2007) & 0.16 & NA & \\
\hline
\end{tabular}

NA: Not available.

a Data for antibiotic use between 2009 and 2011 was obtained from: R. Gudding, Norwegian Veterinary Institute, Pers. Comm., 2013. 
preparation (i.e., biosecurity) than non-certified small- and mediumscale farmers (Table S7, Fig. S1).

\subsection{Study limitations and recommendations}

Given the limited number of interviewed farmers within each farm group, generalizations (e.g. to a species-country level) should carefully take into account the characteristics and type of production systems included in each of the studied farm groups. Moreover, further studies should also focus on chemical application patterns in hatcheries, nurseries and broodstock production, in order to get a comprehensive overview of the amounts of chemicals applied throughout the entire life cycle of aquaculture products. The majority of the grow-out farmers visited in the present study were producing for international markets, with the exception of some tilapia farms in Thailand. Future research should therefore look at different market segments, as export oriented products of Asian countries may often need to comply to more strict regulations than those aimed for domestic markets. Another challenge faced with some of the interviewed farm groups, was polyculture of more than one aquatic species, making it difficult to distinguish the main target species for which the chemical treatment was used for. In such cases, we assumed that significant investments would only be made for the primary (most valuable) species. Given this, and a number of other assumptions made during the calculation of the chemical application volumes, the final calculated values must be considered as estimations, and the variability observed in the results should be taken into account when using the calculated values for follow-up studies. Moreover, future studies investigating factors related to chemical use patterns should also preferably consider variability in disease occurrence and diagnostic capacity, in relation to therapeutic treatments, as important potential drivers for chemical use. The chemical inventories generated in the farm supply shops were found to be a useful source of information to get a broader picture on the status on chemical use, identify substances that are being introduced in the market, and for confirming the active ingredients commonly used by farmers. We therefore recommend such an approach for further surveys aimed at identifying chemical ingredients and evaluating chemical use dosages by aquaculture farmers in Asia.

\section{Acknowledgements}

This study has been funded by the EU-FP7 Sustaining Ethical Aquaculture Trade (SEAT) project (contract number 222889; www. seatglobal.eu). The authors of the manuscript would like to express our extreme gratitude to all the interviewed farmers and chemical sellers for their time and kind responses. We are indebted to the staff members of Kasetsart University (Thailand), Can Tho University (Vietnam), Bangladesh Agricultural University (Bangladesh), and Shanghai Ocean University (China) for conducting the surveys and for their collaboration in data entry.

\section{Appendix A. Supplementary data}

Supplementary data to this article can be found online at http://dx. doi.org/10.1016/j.aquaculture.2013.07.028.

\section{References}

Alday-Sanz, V., Corsin, F., Irde, E., Bondad-Reantaso, M.G., 2012. Survey on the use of veterinary medicines in aquaculture. In: Bondad-Reantaso, M.G., Arthur, J.R., Subasinghe, R.P. (Eds.), Improving biosecurity through prudent and responsible use of veterinary medicines in aquatic food production. FAO Fisheries and Aquaculture Technical Paper No. 547. FAO, Rome, pp. 29-44 (207 pp.).

Arthur, J.R., Lavilla-Pitogo, C.R., Subasinghe, R.P., 2000. Use of chemicals in aquaculture in Asia. Proceedings of the Meeting on the Use of Chemicals in Aquaculture in Asia. 2022th May of 1996. Rigbauan, Iloilo, Philippines. SEAFDEC, Philippines, p. 235.

Bartie, K.L., Austin, F.W., Diab, A., Dickson, C., Dung, T.T., Giacomini, M., Crumlish, M., 2012. Intraspecific diversity of Edwardsiella ictaluri isolates from diseased freshwater catfish, Pangasianodon hypophthalmus (Sauvage), cultured in the Mekong Delta, Vietnam. Journal of Fish Diseases 35, 671-682.

BDOF, 2011. Fish Hatchery Act of 2011. Available at: http://www.fisheries.gov.bd.

Bondad-Reantaso, M.G., Subasinghe, R.P., Arthur, J.R., Ogawa, K., Chinabut, S., Adlard, R. Tan, Z., Shariff, M., 2005. Disease and health management in Asian aquaculture. Veterinary Parasitology 132, 249-272.

Bravo, S., 2012. Environmental impacts and management of veterinary medicines in aquaculture: the case of salmon aquaculture in Chile. In: Bondad-Reantaso, M.G., Arthur, J.R., Subasinghe, R.P. (Eds.), Improving biosecurity through prudent and responsible use of veterinary medicines in aquatic food production. FAO Fisheries and Aquaculture Technical Paper No. 547. FAO, Rome (207 pp.).

Burridge, L., Weis, J.S., Cabello, F., Pizarro, J., Bostick, K., 2010. Chemical use in salmon aquaculture: a review of current practices and possible environmental effects. Aquaculture 306, 7-23.

CMA, 2002. Regulation NY 5071-2002 on Pollution free aquatic products - fishery drugs application guideline.

Dung, T.T., 2011. Trial on vaccine against 'Bacillus Necrosis Pangasius'(BNP) in grow-out Pangasius culture. Vietfish International 8 (4), 76-80.

Dung, T.T., Haesebrouk, F., Tuan, N.A., Sorgeloos, P., Baele, M., Decostere, A., 2008. Antimicrobial susceptibility pattern of Edwardsiella ictaluri isolates from natural outbreaks of bacillary necrosis of Pangasianodon hypophthalmus in Vietnam. Microbial Drug Resistance 14, 311-316.

Dung, T.T., Haesebrouck, F., Sorgeloos, P., Tuan, N.A., Pasmans, F., Smet, A., Decostere, A 2009. IncK plasmid-mediated tetracycline resistance in Edwardsiella ictaluri isolates from diseased freshwater catfish in Vietnam. Aquaculture 295, 157-159.

FAO, Food and Agriculture Organization of the United Nations, 2012a. State of the world fisheries and aquaculture in 2012. FAO fisheries and aquaculture department, Rome, Italy 230.

FAO, Food and Agriculture Organization of the United Nations, 2012b. FishStat Plus. Fishery statistical collections. (Released: 18th April 2012. Italy, Rome. Available at: http:// www.fao.org/fishery/statistics/software/fishstat/en).

Grave, K., Torren-Edo, J., Mackay, D., 2010. Comparison of the sales of veterinary antibacterial agents between 10 European countries. Journal of Antimicrobial Chemotherapy 5, 2037-2040.

Gudding, R., 2012. Disease prevention as a basis for sustainable aquaculture. In: BondadReantaso, M.G., Arthur, J.R., Subasinghe, R.P. (Eds.), Improving biosecurity through prudent and responsible use of veterinary medicines in aquatic food production. FAO Fisheries and Aquaculture Technical Paper No. 547. FAO, Rome (207 pp.).

Heuer, O.E., Kruse, H., Grave, K., Collignon, P., Karunasagar, I., Angulo, F.J., 2009. Human health consequences of use of antimicrobial agents in aquaculture. Food Safety 29 , 1248-1253.

Holmström, K., Gräslund, S., Wahlström, A., Poungshompoo, S., Bengtsson, B.E., Kautsky, N., 2003. Antibiotic use in shrimp farming and implications for environmental impacts and human health. International Journal of Food Science and Technology 38, 255-266.

Le, T.X., Munekage, Y., 2004. Residues of selected antibiotics in water and mud from shrimp ponds in mangrove areas in Viet Nam. Marine Pollution Bulletin 49, 922-929.

Le, T.X., Munekage, Y., Kato, S.I., 2005. Antibiotic resistance in bacteria from shrimp farming in mangrove areas. Science of the Total Environment 349, 95-105.

Lebel, L., Mungkung, R., Gheewala, S.H., Lebel, P., 2010. Innovation cycles, niches and sustainability in the shrimp aquaculture industry in Thailand. Environmental Science \& Policy 13, 291-302.

Love, D.C., Rodman, S., Neff, R.A., Nachman, K.E., 2011. Veterinary drug residues in seafood inspected by the European Union, United States, Canada, and Japan from 2000 to 2009. Environmental Science and Technology 45 (17), 7232-7240.

Murray, F.J., Clausen, J., Dalsgaard, A., Karunasagar, I., Morris, D., 2012. The EU Rapid Alert System for Foods and Feeds (RASFF): an indicator of non-compliance in seafood trade and challenges to producer countries. Proc. of the World Aquaculture Society Conference, 1-5th of September of 2012. Prague, Czech Republic.

Murray, F.J., Haque, M.M., Zhang, W., Thanh, L.P., Nietes Satapornvanit, A., Little, D.C., 2013. Defining boundaries towards understanding sustainable ethical aquaculture trade between Asia and Europe. SEAT Project Report 2.8.University of Stirling, Stirling, UK.

$\mathrm{NIPH}, 2009$. Pharmaceutical use in Norwegian fish farming in 2001-2008. Electronic Citation. Accessed January 2013: (http://www.fhi.no/eway/default.aspx?pid=233\&trg=Area 5774\&MainLeft_5669=5774:0:\&Area_5774=5544:73848::0:5776:1:::0:0).

Noga, E.J., 1996. Fish Disease. Diagnosis and Treatment. Mosby-Year Book, Inc., Missoure. US 367.

Phan, L.T., Bui, T.M., Nguyen, T.T.T., Gooley, G.J., Ingram, B.A., Nguyen, H.V., Nguyen, P.T., De Silva, S., 2009. Current status of farming practices of striped catfish, Pangasianodon hypophthalmus, in the Mekong Delta, Vietnam. Aquaculture 296, 227-236.

Phuong, N.T., 2010. Analytical and biological methods in support of sustainable aquaculture practices in Vietnam. A joint Vietnamese-Belgian project FUNDED BY SPO. Final report (May 2007-April 2009).

Rico, A., Satapornvanit, K., Haque, M.M., Min, J., Nguyen, P.T., Telfer, T.C., Van den Brink, P.J., 2012. Use of chemicals and biological products in Asian aquaculture and their potential environmental risks: a critical review. Reviews in Aquaculture 4, 75-93.

Sapkota, A., Sapkota, A.R., Kucharski, M., Burke, J., McKenzie, S., Walker, P., Lawrence, R. 2008. Aquaculture practices and potential human health risks: current knowledge and future priorities. Environmental International 34 (8), 1215-1226.

Srivastava, S., Sinha, R., Roy, D., 2004. Toxicological effects of malachite green. Aquatic Toxicology 66 (3), 319-329.

Tai, M.V., 2012. Use of veterinary medicines in Vietnamese aquaculture: current status. In: Bondad-Reantaso, M.G., Arthur, J.R., Subasinghe, R.P. (Eds.), Improving biosecurity through prudent and responsible use of veterinary medicines in aquatic food production. FAO Fisheries and Aquaculture Technical Paper No. 547. FAO, Rome (207 pp.). 
Ter Braak, C.J.F., Smilauer, P., 2012. CANOCO (version 5). Software for multivariate data exploration, testing and summarization.Microcomputer Power, Ithaca, NY, USA.

Thinh, N.H., Kuo, T.Y., Hung, L.T., Loc, T.H., Chen, S.C., Evensen, O., Schuurman, H.J., 2009 Combined immersion and oral vaccination of Vietnamese catfish (Pangasianodon hypophthalmus) confers protection against mortality caused by Edwardsiella ictaluri. Fish and Shellfish Immunology 27, 773-776.

Tu, H.T., Phuong, N.T., Silvestre, F., Douny, C., Tao, C.T., Maghuin-Rogister, G., Kestemont P. 2006. Investigation on the use of drugs and chemicals in shrimp farming and the kinetics of enrofloxacin and furazolidone in black tiger shrimp (Penaeus monodon). Science Journal of Can Tho University 1, 70-78 (In Vietnamese).
Tukwinas, S., 2002. Auditing system for quality cultured shrimp by the Department of Fisheries. Thai Fisheries Gazette, Volume 55, No. 3, May-June 2002. 227-243 Fisheries.
(In Thai)

VMARD, 2009. Circular No 15/2009/TT-BNN, dated 17/3/2009, on the list of drugs, chemicals and antibiotics banned or restricted to use in Vietnamese aquaculture (In Vietnamese).

VMARD, Ministry of Agriculture and Rural Development of Vietnam, 2012. Cicular No.03/ 2012/TT-BNN dated January 16, 2012 on removing Cypermethrin, Deltamethrin and Enrofloxacin from the list of limited veterinary drugs and products use in aquaculture and adding Cypermethrin. Deltamethrin and Enrofloxacin to the list of banned veterinary drugs and products use in aquaculture. (In Vietnamese). 